\title{
Corporate Ownership Structure and Bank Loan Syndicate Structure*
}

\author{
Chen Lin \\ Yue Ma \\ Chinese University of Hong Kong \\ Lingnan University, Hong Kong \\ Paul Malatesta \\ Yuhai Xuan \\ University of Washington \\ Harvard Business School
}

March 7, 2011

\begin{abstract}
This paper examines the relation between corporate ownership structure and bank loan syndicate structure. We find that the divergence between control rights and cash-flow rights of a borrowing firm's largest ultimate owner has a significant impact on the concentration and composition of the firm's loan syndicate. When the control-ownership divergence is large, lead arrangers form syndicates with structures that facilitate enhanced due diligence and monitoring efforts. These syndicates tend to be relatively concentrated and comprised of domestic banks that are geographically close to the borrowing firms and that have lending expertise related to the industries of the borrowers. We also examine factors that influence the relation between ownership structure and syndicate structure, including firm opacity, presence of multiple large owners, bank reputation, lending relationship, law and institution, and financial crises.
\end{abstract}

\footnotetext{
* We thank the editor, Bill Schwert, and an anonymous referee for detailed comments and helpful suggestions. We thank Ben Esty, Stuart Gilson, Paul Gompers, Joel Houston, Victoria Ivashina, Christopher James, Simon Johnson, Rafael La Porta, Andrei Shleifer, Laura Starks, Jeremy Stein, Belén Villalonga, and Yihui Wang for thoughtful discussions. We thank Arbitor Ma, Pennie Wong, and William Alden for help with data collection. Lin and Xuan gratefully acknowledge financial support from Chinese University of Hong Kong and the Division of Research of the Harvard Business School, respectively.
} 


\section{Introduction}

Over the past two decades, the syndicated loan market has become the most important source of global corporate financing. International syndicated lending amounted to \$1.8 trillion in 2009, surpassing the $\$ 1.5$ trillion of corporate borrowing in international bond markets (Chui et al., 2010). Unlike a traditional bank loan, which typically involves a single creditor, a syndicated loan unites a group of lenders in which a lead arranger originates the loan and performs due diligence and monitoring, and the participant banks fund parts of the loan (Esty, 2001). The syndication process therefore generates an additional element of moral hazard within the syndicate between the lead arranger and the other syndicate members, besides the typical agency problems between the borrower and the lender that exist in a lending relationship (Diamond, 1984; Holmstrom and Tirole, 1997). Despite the importance of syndicated loans and the uniqueness of the syndication process, little is known about how loan syndicates are structured to address and mitigate moral hazard problems both at the borrowing firm and within the syndicate.

In this paper, we focus on the divergence between corporate ownership and control at the borrowing firm to explore how corporate ownership structure influences the bank loan syndicate structure. In many publicly listed firms around the world, control rights of the dominant shareholders often exceed their cash-flow rights via the use of dual-class shares, pyramidal structures, and multiple control chains (e.g., La Porta et al., 1999; Claessens et al., 2000; Laeven and Levine, 2008, 2009; Gompers et al., 2010). In such firms, the controlling shareholders have the ability to divert corporate wealth for private benefits without bearing the full financial consequences, and therefore have strong incentives to engage in tunneling and other moral hazard activities (Shleifer and Vishny, 1997; Johnson et al., 2000a). ${ }^{1}$ Many of

\footnotetext{
1 Various forms of such activities by controlling shareholders are documented in developed countries as well as developing countries. They include outright theft or fraud, expropriation of corporate opportunities, and self-serving financial transactions such as transfer pricing, inter-corporate loans, asset sales at favorable prices to controlling shareholders, etc. (e.g., Djankov et al., 2008).
} 
these activities increase the default risks, impair collateral values and, as a consequence, increase the expected costs of financial distress (Lin et al., 2011). ${ }^{2}$ In anticipation of the increased credit risk, more intense due diligence and monitoring efforts are required before lending takes place. However, as suggested in the framework of Holmstrom and Tirole (1997), the lead arranger has an incentive to shirk the monitoring responsibilities, especially when more intense monitoring is required, because the monitoring efforts are costly and unobservable, and the lead arranger only owns part of the loan. The lead arranger bears most of the costs for the due diligence on the borrower ex ante and the monitoring of the borrower ex post yet retains only a fraction of the loan. Therefore, the lead arranger may lack the incentive to provide the optimal level of efforts (Sufi, 2007; Ivashina, 2009). Participant banks should take the lead arranger's moral hazard problem into account and demand that a greater fraction of the loan be held by the lead arranger for incentive purposes if the borrowing firm requires more due diligence and monitoring. Moreover, a larger portion of the loan retained by the lead arranger not only signals a credible commitment by the lead arranger in due diligence and monitoring, but also provides a strong signal of borrower quality (Sufi, 2007; Ivashina, 2009). Therefore, the fraction held by the lead arranger of a syndicated loan should be increasing in the divergence between control and cash-flow rights of the borrowing firm's dominant shareholders. It follows that syndicates lending to firms with large control-ownership deviations should be more concentrated than those lending to firms with small deviations.

On the other hand, there might be countervailing factors that induce a diffuse syndicate ownership structure in the face of control-ownership divergence. Diffuse loan ownership can facilitate diversification of risk exposure across lenders (Esty and Megginson, 2003). As the credit risks increase with the corporate control-ownership divergence, creditor diversification incentives also increase. In addition, a more diffuse syndicate ownership makes renegotiation

\footnotetext{
${ }^{2}$ For instance, Friedman et al. (2003) report that bankruptcy cases in many countries are associated with
} complete looting by controlling shareholders, leaving the creditors practically nothing when the firms go bankrupt. 
more difficult and restructuring more costly (Gertner and Scharfstein, 1991; Bolton and Scharfstein, 1996; Brunner and Krahnen, 2008). As a consequence, diffuse loan ownership can be used as a pre-commitment mechanism by lenders to deter strategic defaults (Bolton and Scharfstein, 1996; Esty and Megginson, 2003). Therefore, if creditors are concerned with strategic defaults by the borrowing firms when there is a large divergence between corporate control and cash-flow rights, a diffuse syndicate ownership might be preferred. In this regard, the creditors' incentives to form a more diffuse syndicate might be increasing in the divergence between corporate control and cash-flow rights. These considerations suggest a negative relation between corporate control-ownership divergence and syndicate concentration. The overall effect of corporate control-ownership divergence on syndicate concentration is an empirical question that we will explore in this study.

The divergence between ownership and control at the borrowing firm can also affect the composition of the loan syndicate, including foreign lender participation and the overall lending expertise of the syndicate members. It is well documented that greater physical distance between the lender and the borrower makes the ex-ante screening and ex-post monitoring more difficult and generates higher agency costs (Stein, 2002; Esty, 2004). The distance-driven agency costs are further aggravated by the agency problems induced by the control-ownership divergence at the borrowing firms. As a result, foreign banks might be less willing to lend to such firms that require monitoring-intensive relationship loans. Moreover, as Esty (2004) suggests, foreign banks are more susceptible to expropriation risks because they are often treated unfairly in corporate default situations, especially in relational functions such as debt restructuring or collateral seizing. ${ }^{3}$ Therefore, we expect the syndicate participation rate of foreign lenders to be negatively related to the divergence between control and cash-flow rights of the dominant shareholders of the borrower.

3 Esty (2004) reports numerous cases on discrimination against foreign creditors in various countries including the U.S. One vivid example involves Jasmine International, a Thai telecommunications company founded by Thailand's commerce minister and controlled by his family. After the company went into financial distress during the Asian financial crisis and had to restructure its debt, it proposed to repay its local creditors in full while repaying less than $20 \%$ of the debt owed to foreign lenders. 
The lending expertise of the syndicate also may be affected by the divergence between ownership and control at the borrowing firm. Lender loan portfolio concentration in a particular industry is driven by synergies in information collection and monitoring (Ivashina, 2009). Banks with industry-specific expertise are more likely than other banks to lend to borrowers that require industry-specific knowledge and intense monitoring, such as firms with great tunneling risks caused by large divergences between ownership and control. Furthermore, given the heightened risks and the potential need for joint monitoring at such firms, the lead arranger is likely to select participant lenders based on their familiarity with the borrowing firm's industry sector. Syndicates lending to firms with large control-ownership divergences, therefore, are likely to be comprised of banks with expertise and experience in lending to firms in the borrower's industry.

Our empirical analysis finds evidence that is consistent with our expectations. Specifically, we use a novel, hand-collected data set on corporate ownership and control of 3,056 firms in 22 Western European and East Asian countries from 1996 to 2008 to examine the relation between the control-ownership divergence at borrowing firms and the structure of lending syndicates. We obtain detailed information on 14,350 syndicated loans made to these sample firms, and for each firm, we track its ownership chain and compute the cash-flow and control rights of its ultimate largest owner. Our results indicate that the divergence between control rights and cash-flow rights of a borrowing firm's largest ultimate owner has a significant impact on the concentration and composition of the firm's loan syndicate. Ceteris paribus, a one-standard-deviation increase in the control-ownership divergence at the borrowing firm increases the amount of the loan held by the lead arranger by $14 \%$ and increases average syndicate concentration measured by a Herfindahl index by $17 \%$. With respect to the syndicate composition, a one-standard-deviation increase in the divergence is associated with a $19 \%$ decrease in foreign bank participation (based on the number of foreign lenders in the syndicate and the percentage of loan held by all foreign lenders) and a $16 \%$ increase in the overall syndicate lending expertise related to the borrowing firm's industry. The estimated 
effects of the control-ownership divergence on syndicate structure are both economically and statistically significant.

We further examine the factors that influence the relation between the control-ownership divergence and the syndicate structure to explore the channels through which the tunneling and self-dealing risks and the associated monitoring needs induced by the control-ownership divergence at the borrowing firm can be exacerbated or mitigated. We find that if the lead arranger has a strong reputation and prior lending relationships with the borrowing firm, the relation between control-ownership divergence and syndicate structure is weaker than otherwise. Similarly, law and institutions such as strong shareholder rights and good credit information sharing systems, which constrain self-dealing activities and impose market-based discipline, moderate the relation between control-ownership divergence and syndicate structure. ${ }^{4}$

On the other hand, our results indicate that the effect of the excess control rights on loan syndicate structure is more pronounced for firms with higher degrees of informational opacity such as small firms, firms without credit ratings, and firms with low analyst coverage. Moreover, we also investigate the effect of the difference in cash-flow rights dispersion between the largest and second largest shareholders of the borrowing firm on the relation between syndicate structure and control-ownership divergence. Laeven and Levine (2008) argue that unequal distribution of cash-flow rights across large owners impedes external monitoring and thus enhances the ability of the controlling shareholder to divert corporate resources for private benefits. ${ }^{5} \quad$ Accordingly, we find that the dispersion of cash-flow rights across large owners amplifies the effect of the control-ownership divergence on syndicate structure.

\footnotetext{
${ }^{4}$ Strong shareholder rights reduce self-dealing and tunneling activities (Djankov et al., 2008). Information sharing among creditors improves banks' knowledge of the characteristics and credit histories of borrowers and applicants (Barth et al., 2009), and in addition, works as a post-lending disciplining device by making it more difficult for borrowers with negative histories (e.g., late repayment, default, etc.) to get access to credit in the future (Padilla and Pagano, 1997; Houston et al., 2010).

${ }^{5}$ Laeven and Levine (2008) also show that the cash-flow rights dispersion between the largest and the second largest shareholders is negatively related to firm value.
} 
We examine also the relation between control-ownership divergence and syndicate structure during financial crises. Financial crises represent relatively exogenous shocks that reduce the return on investment of all firms, thereby increasing the difficulty of investor monitoring and lowering the marginal cost of insiders' expropriation activities (Johnson et al., 2000b; Johnson and Mitton, 2003). Consistent with this notion, we find that the effect of control-ownership divergence on syndicate structure is particularly strong for borrowers in countries experiencing financial crises.

One potential source of concern for our empirical analysis is the issue of endogeneity. While it is rather unlikely that a borrowing firm determines its ownership structure as a direct function of the syndicate structure of its loan, the borrower might have characteristics unaccounted for in our study that jointly determine the control-ownership divergence and the syndicate structure. The consistent results from the sharper interaction tests on factors that affect the divergence-syndicate structure relation help to alleviate this concern. In the spirit of Rajan and Zingales (1998), one way to overcome some of the endogeneity concerns is to focus on the details of theoretical mechanisms through which corporate ownership structure affects syndicate structure, and document their working. The various interaction term effects discussed above could in effect be viewed as "the 'smoking gun' in the debate about causality" (Rajan and Zingales, 1998). Moreover, it is less likely to have an omitted variable correlated with the interactive terms than with the linear term (Raddatz, 2006). Thus, from an econometric perspective, the interactive term approach is also less subject to endogeneity concerns (Claessens and Laeven, 2003). In sum, the various interaction test findings show direct evidence about how corporate ownership structure affects syndicate structure, thus providing a stronger test of causality and alleviating endogeneity concerns.

Furthermore, we perform two additional tests to address the endogeneity issue. First, we test the robustness of the results by including country $\times$ year fixed effects and industry $\times y e a r$ fixed effects, respectively. The inclusion of these fixed effects controls for the omitted industry and country effects that might affect syndicate structure and thus helps to mitigate the 
endogeneity concerns. Second, we instrument for each borrower's control-ownership divergence and cash-flow rights using the initial industry average control-ownership divergence and the initial industry average cash-flow rights in the borrower's industry as respective instruments (Laeven and Levine, 2009; Lin et al., 2011). As Laeven and Levine (2009) suggest, an individual firm's ownership structure is correlated with the industry average ownership structure. However, it is unlikely that the industry ownership structure directly affects the syndicate structure of any particular loan of the borrowing firm except through the borrower's ownership structure. The estimation results remain economically and statistically significant using either approach, further alleviating the concern that endogeneity biases our main findings.

In focusing on how bank financing is arranged to mitigate the agency costs associated with the divergence between ownership and control in an international context, this paper contributes to the ownership structure literature (e.g., La Porta et al., 1999; Claessens et al., 2002; Laeven and Levine, 2008), the financial contracting literature (e.g., Sufi, 2007; Qian and Strahan, 2007; Graham et al., 2008; Campello et al., 2010; Demiroglu and James, 2010a), and the international banking literature (e.g., Beck et al., 2006; Laeven and Levine, 2007; Houston et al., 2010). Taken together, our results suggest that corporate ownership structure has a significant impact on bank loan syndicate structure. These results are consistent with the hypothesis that the divergence between control rights and cash-flow rights in the borrowing firms exacerbates potential tunneling and other agency problems by large shareholders, thereby increasing the credit risk faced by lenders. Consequently, when the deviation between the control and cash-flow rights of a borrower's dominant shareholder is large, lead arrangers respond by forming syndicates with structures that facilitate enhanced due diligence and monitoring efforts. These syndicates tend to be relatively concentrated, with the lead arrangers holding a relatively large fraction of the loan. Moreover, the syndicates tend to be comprised of domestic banks that are geographically close to the borrowing firms and that have lending expertise related to the industries of the borrowers. 
The remainder of the paper proceeds as follows. Section 2 describes the sample construction process and variable definitions. Section 3 presents the empirical results. Section 4 concludes.

\section{Data and variables}

\subsection{Sample construction}

We start building our sample using the combined data sets in Claessens et al. (2000) and Faccio and Lang (2002). These two data sets contain ownership and control information during the 1996-1999 period for the corporations in 22 Western European and East Asian countries (regions) including Austria, Belgium, Finland, France, Germany, Ireland, Italy, Norway, Portugal, Spain, Sweden, Switzerland, the United Kingdom, Hong Kong, Indonesia, Japan, Malaysia, Philippines, Singapore, South Korea, Taiwan, and Thailand. We then manually match these firms by name to the Dealscan database provided by Thomson Reuters. To be retained in the sample, a firm must have detailed information available on its loan contracts and transactions in Dealscan's coverage of the global loan markets.

Next, we hand-collect information on ultimate ownership and control for the sample firms beyond 1999 and up to $2008 .^{6} \quad$ To make the manual collection workload manageable, we follow Claessens et al. (2000) and Faccio and Lang (2002) and augment the ownership data for the 2000-2008 period in three blocks: 2000-2003, 2004-2006, and 2007-2008. ${ }^{7}$ We use years 2002, 2005, and 2007 as the base years for information collection. If firm ownership data cannot be located in a base year, we search the other years in the corresponding block

\footnotetext{
${ }^{6}$ Lin et al. (2011) use a similar sample construction methodology; see the paper for a detailed discussion.

7 The 1996-1999 ownership data in Claessens et al. (2000) and Faccio and Lang (2002) are computed at a chosen year between 1996 and 1999 . Over short time periods, firm ownership structures do not tend to vary much (La Porta et al., 1999; Faccio and Lang, 2002).
} 
period. To track each firm's ownership chain, we use the Factset, OSIRIS, and Worldscope global databases. ${ }^{8}$ Since large shareholders of a firm are often corporations themselves, we trace backward the control chain through numerous layers of ownership until we identify the ultimate controlling shareholder: a family, the government, or a widely held corporation. Consistent with the ownership literature (e.g., La Porta et al., 1999; Laeven and Levine, 2008), we use $10 \%$ as the threshold of voting rights above which the shareholder is assumed to have effective control over the intermediate corporations and at the ultimate level. ${ }^{9}$ A firm is classified as widely held if none of its owners has $10 \%$ of the voting rights. This procedure yields our final ownership data set that covers 3,056 firms in 22 countries from the period 1996 to 2008 for which we have available loan contract information from Dealscan and firm financial information from Worldscope. Our final sample of loan deals contains 14,350 syndicated loans to these sample firms during the sample period.

\subsection{Cash-flow rights and control rights of the largest ultimate owner}

We apply the standard methodology in the ownership literature to construct the ultimate ownership and control measures using the complete chain of corporate ownership (e.g., Claessens et al., 2000; Faccio and Lang, 2002; Laeven and Levine, 2008; Lin et al., 2011). The cash-flow rights of the ultimate owner are calculated as the sum of direct cash-flow rights and indirect cash-flow rights. Direct cash-flow rights are computed based on direct ownership, which involves shares held under the shareholder's name. Indirect ownership involves shares held by entities controlled by the ultimate shareholder. We compute indirect cash-flow rights by multiplying the cash-flow rights along the ownership chain until we reach the ultimate

\footnotetext{
${ }^{8}$ We start our ownership search in OSIRIS and then search Factset and Worldscope if information is not available in OSIRIS.

9 Our results are robust to using alternative thresholds, such as $20 \%$.
} 
owner of the firm. Due to the use of pyramid structures, cross-ownership, and dual-class shares, control rights can be different from cash-flow rights. The ultimate owner's aggregate control rights are the sum of direct control rights and indirect control rights. In the chain of control, indirect control rights are measured by the weakest link in the chain of control rights. The following simple example illustrates how indirect cash-flow rights and control rights are calculated. Suppose that a family owns fraction $a$ of firm A, which in turn owns fraction $b$ of firm $\mathrm{B}$, and that both $a$ and $b$ are greater than the effective control threshold. Then the family's indirect cash-flow rights in firm B is the product of $a$ and $b$, the two ownership stakes along the chain. Its indirect control rights in firm $\mathrm{B}$ is $\min (a, b){ }^{10}$

Following the above procedure, we calculate for each sample firm the cash-flow rights and control rights of its largest ultimate owner, defined as the ultimate owner that has the greatest aggregate control rights. We then define the control-ownership wedge as the difference between the control rights and cash-flow rights of the largest ultimate owner of the firm (La Porta et al., 1999; Claessens et al., 2000; Claessens et al., 2002; Faccio and Lang, 2002; Laeven and Levine, 2008). This is our key measure to capture the divergence between control rights and cash-flow rights. Our results are robust to using alternative measures such as the ratio of control rights to cash-flow rights or a dummy variable that indicates whether control rights exceeds cash-flow rights.

\subsection{Bank loan syndicate structure}

Syndicated loans involve a group of lenders united by a common set of legal documents for the purpose of providing funds to a single borrower. ${ }^{11}$ The syndication process typically starts with a borrower awarding the mandate to a lead arranger, who administers and advises the

\footnotetext{
${ }^{10}$ Claessens et al. (2000) and Faccio and Lang (2002) provide and discuss many more complex examples.

11 See Esty $(2001,2003)$ and Rhodes et al. (2000) for more detailed discussions of the syndication process.
} 
syndicate. The lead arranger analyzes credit quality, and negotiates key terms with the borrower before inviting a group of banks to participate, and finally is responsible for allocating shares of the loan among the participating banks. As discussed in the introduction, one way to increase the exposure of the lead lender is by having it hold a larger portion of the loan. Conceptually, an alternative mechanism for exposing the lead lender is to contractually force the lead lender to absorb a higher percentage of any initial losses. Much as syndicate concentration, this internal structured finance dimension of the syndicated loan would provide a strong and credible signal of credit quality as well as the commitment by the lead arranger in performing due diligence and monitoring.

However, such a mechanism is not implemented in practice. Although the lead arranger's due diligence summary is furnished to every participating bank in a memorandum prior to the invitation, each participating bank is ultimately responsible for its own assessment of the borrower's credit quality (Esty 2001). A typical syndicated loan agreement includes extensive disclaimers of the lead arranger's responsibility, and the lead arranger owes no fiduciary duties to any participating banks (Ivashina, 2009). If the borrower defaults, participating banks have no recourse against the lead arranger (McCahey, 2003; Wight et al., 2009; Goplan et al., 2010). Syndicated loan agreements are typically structured such that no recourse rights are granted to a participating lender against the lead lender for non-payment of the loan in order for the control of the portion of the loan sold to the participating lender to be considered effectively transferred from the lead arranger to the participating lender. Otherwise, the portion of loan could be considered the lead lender's contingent liability and therefore incur a capital requirement. Even implicit agreements between the lead lender and participating lenders for the lead lender to absorb initial losses or buy back a participant bank's portion of the loan in the event of default create problems under risk-based capital standards (Martin, 2009). Consequently, in practice, risk sharing in syndicated loans is on a pro rata basis based on each lender's share in the loan (Wight et al., 2009). In this paper, we therefore focus on syndicate concentration as the mechanism for exposing the lead arranger because retaining a large portion of the loan is 
relatively easy to implement without much complication and at the same time provides a credible signal of the lead arranger's commitment.

We focus on two aspects of the bank loan syndicate structure: syndicate concentration and syndicate composition. For each loan facility, our proxies for syndicate concentration include the total number of lenders, the dollar amount and percentage of the loan kept by the lead arranger, and the Herfindahl index based on lenders' shares (Sufi, 2007). ${ }^{12}$ We calculate the fraction of the loan held by the lead arranger and multiply by 100 to arrive at the percentage measure. If a syndicated loan has more than one lead arranger, we examine the total dollar amount and percentage of the loan kept by all the lead arrangers. Using an alternative measure of the average dollar amount and percentage of the loan kept by each lead arranger produces robust results. We define the Herfindahl index as the sum of the squares of each lender' share in the loan. It ranges from 0 to 1 , with higher index values indicating higher degrees of concentration of holdings within a syndicate.

To study syndicate composition, we examine foreign lender participation and syndicate industry expertise. For each loan facility, our proxies for foreign lender participation include the total number of foreign lenders and the total percentage of the loan held by all foreign lenders combined. We construct two measures to capture each syndicate's overall lender expertise in the borrower's industry. For each lender in a syndicate, we first calculate the total amount of loans it has made over the past five years to firms in the same three-digit SIC industry as the borrower and then divide this amount by the total amount of loans issued in the same industry over the same period by all the lenders in Dealscan. ${ }^{13}$ A higher ratio from this calculation, hereafter referred to as the industry expertise ratio, indicates more accumulated experience and expertise of the lender in lending to the borrower's particular industry. Our first measure of syndicate industry expertise is the sum of the industry expertise ratios of all the

\footnotetext{
${ }^{12}$ Variables requiring information on the amount of loan held by each lender to calculate have fewer observations than the concentration variables due to missing data in Dealscan.

${ }^{13}$ All our results are robust to using alternative time windows or alternative SIC industry groupings.
} 
lenders in the syndicate. To account for the difference in each lender's share in the loan, we also construct a second measure as the weighted average of the industry expertise ratios of all the lenders in the syndicate, with each lender's share in the loan as its weight.

\subsection{Control variables}

We use a rich set of control variables to capture various characteristics and factors other than ownership structure that might influence the loan syndicate structure. We account for borrower firm characteristics including firm size, profitability, leverage, $Q$, asset tangibility, cash-flow volatility, and S\&P credit rating. ${ }^{14}$ We also control for loan characteristics including loan size, loan maturity, loan purpose, whether the facility is a term loan or a revolver, and whether the loan includes contingent performance-based pricing. Another set of control variables are macroeconomic factors that capture the economic and financial development as well as the sovereign risk at the country level. These variables include GDP per capita, private credit to GDP, and sovereign bond rating. Finally, we control for country, borrower industry and year fixed effects.

The detailed definitions for these variables as well as all the other variables used in this paper are reported in Table 1. Table 2 presents summary statistics for the entire sample.

[Insert Tables 1 and 2 here]

\section{Results}

\subsection{The effect of the control-ownership divergence on syndicate structure}

${ }^{14} \mathrm{~S} \& \mathrm{P}$ ratings are converted to an index from one to seven, with one assigned to the highest AAA rating and seven assigned to firms that do not have a credit rating. 
In this section we investigate the impact of the deviation between the control rights and cash-flow rights of a borrowing firm's largest ultimate owner on its bank loan syndicate structure. We estimate the following empirical model using ordinary least squares (OLS) regressions:

Syndicate structure $=f($ Control-ownership wedge, Borrower characteristics, Loan characteristics, Macroeconomic factors, Country, industry and time effects).

In the regressions, each observation represents a single loan. As explained in the previous section, the dependent syndicate structure variables are measures of syndicate concentration and syndicate composition. Our key independent variable of interest is the control-ownership wedge, which captures the divergence between the control rights and cash-flow rights of the borrowing firm's largest ultimate owner. We control for the cash-flow rights of the borrower's largest ultimate owner and other borrower characteristics, loan-specific characteristics, and country-level macroeconomic factors, as well as country, borrower industry and year fixed effects. All standard errors are corrected for heteroskedasticity and are clustered at the borrowing firm level.

[Insert Table 3 here]

Table 3 presents the regression results of estimating Eq. (1). We focus on syndicate concentration first, and then examine syndicate composition. In the first four columns of Table 3, the dependent variables are different measures of loan syndicate concentration: the total number of lenders (column 1), the dollar amount of the loan kept by the lead arranger (column 2), the percentage of the loan kept by the lead arranger (column 3), and the Herfindahl index of lenders' shares in the loan (column 4). Across all columns, the control-ownership wedge is significantly related to the degree of concentration within the syndicate. Loans to borrowing firms with a larger divergence between the control rights and cash-flow rights of the largest ultimate owner have a more concentrated syndicate: there are fewer lenders in the syndicate, the lead arranger holds a larger amount of the loan both in dollar amount and in 
percentage of the loan, and the lenders' shares in the loan overall have a more concentrated distribution as indicated by a higher Herfindahl index value.

The effect of the control rights-cash-flow rights divergence on syndicate concentration is not only statistically significant (at the 5\% level or better) but also highly significant economically. Ceteris paribus, a one-standard-deviation increase in the control-ownership wedge reduces the number of lenders in the syndicate by more than $21 \%$, increases the amount of the loan held by the lead arranger and the Herfindahl lender share concentration by approximately $14 \%$ and $17 \%$, respectively, and increases the percentage of the loan held by the lead arranger from $57 \%$ (at the mean) to $64 \%$.

Columns 5 through 8 in Table 3 focus on syndicate composition. We study foreign lender participation as well as syndicate industry expertise. The dependent variables we examine include the number of foreign lenders (column 5), the percentage of the loan held by all foreign lenders combined (column 6), and the sum and the lender-share-weighted average of the industry expertise ratios of all the lenders in the syndicate (columns 7 and 8, respectively). Estimates from columns 5 to 8 indicate that corporate ownership structure has a significant impact on syndicate composition. When the borrowing firm's largest ultimate owner has a greater excess of control rights over cash-flow rights, fewer foreign lenders participate in the syndicate, and the syndicate is composed of lenders with greater lending experience and expertise in the borrower's industry, relative to the other lenders. A one-standard-deviation increase in the control-ownership wedge reduces the number of foreign lenders in the syndicate by approximately $19 \%$ and reduces the percentage of the loan held by foreign lenders from $58 \%$ (at the mean) to $47 \%$, but it increases the total and weighted-average industry expertise of the syndicate lenders by $13 \%$ and $16 \%$, respectively. All these effects are also highly significant statistically at the $5 \%$ level or better.

Overall, the results from the multivariate regression analyses suggest that the divergence between control rights and cash-flow rights of the borrowing firm's largest ultimate owner has a significant impact on the syndicate structure of its bank loans. In particular, loans to firms 
with larger control-ownership wedges have more concentrated syndicates with less foreign lender participation and more overall lender expertise in the borrower's industry. These results are consistent with the hypothesis that the deviation of control rights and cash-flow rights in the borrowing firms exacerbates potential tunneling and other agency problems by large shareholders, thereby increasing the credit risk faced by lenders. Consequently, lead arrangers form syndicates with structures that facilitate enhanced due diligence and monitoring efforts. These syndicates are relatively concentrated, with the lead arrangers retaining a relatively large portion of the loan, and are comprised of domestic banks that are geographically close to the borrowing firms and that have relatively more experience in lending to the specific industries of the borrowers. ${ }^{15}$

\subsection{Endogeneity of ownership structure}

In this section, we address the potential endogeneity concern associated with analyzing the effect of corporate ownership structure on loan syndicate structure. While it is unlikely that a borrowing firm determines its ownership structure as a direct function of the syndicate structure of its loan, the borrower might have firm-specific characteristics unobservable or unaccounted for in our baseline model that jointly determine the control-ownership wedge and the syndicate structure. To alleviate the potential bias in our estimation from omitted variables that affect both ownership structure and syndicate structure, we perform two additional tests. First, we include the country $\times$ year and industry $\times$ year fixed effects to fully capture the omitted country and industry characteristics that might affect syndicate structure and test the robustness of the

${ }^{15}$ For brevity of presentation, our analyses in the remainder of the paper use the percentage of loan held by the lead arranger and the Herfindahl index as measures for syndicate concentration and the percentage of loan held by foreign lenders and the weighted-average syndicate industry expertise ratio as measures for syndicate composition. All the results are robust to using the other measures for syndicate concentration and syndicate composition as in Table 3. 
results. Second, we instrument for the borrowing firm's ownership structure and perform instrumental variables regressions.

\subsubsection{Country $\times$ year and industry $\times$ year fixed effects}

In our baseline regressions, we include industry and country dummy variables to control for the time-invariant country and industry characteristics that might affect syndicate structure. However, it is still possible that there are some time-varying country and industry characteristics driving both corporate ownership structure and bank loan syndicate structure. To fully capture these potential effects and alleviate concerns about the omitted variable bias, we test the robustness of our baseline results in Table 4 by adding the country $\times$ year (columns 1 to 4 ) and industry $\times$ year fixed effects (columns 5 to 8 ) in the regression models. ${ }^{16}$

[Insert Table 4 here]

As can be seen from Table 4, the regression results with country×year and industry $\times y e a r$ fixed effects corroborate our baseline findings. Specifically, the corporate control-ownership divergence is positively associated with syndicate concentration and negatively associated with foreign lender participation in the syndicate. Moreover, the corporate control-ownership wedge is positively associated with the industry expertise of the syndicate lenders. All of the effects remain statistically significant at the $1 \%$ level, with very similar magnitudes as in the baseline regressions.

\subsubsection{Instrumental variable estimation}

${ }^{16}$ Note that country-specific variables including sovereign risk rating, private credit to GDP, and log GDP per capita do not enter into the regressions with country $\times$ year fixed effects. 
Our second approach to address the endogeneity issue is to employ instrumental variables estimation. We instrument for each borrowing firm's control-ownership wedge and cash-flow rights using the initial industry average wedge and the initial industry average cash-flow rights in the borrower's industry as respective instruments (Laeven and Levine, 2009). ${ }^{17}$ The initial industry averages are calculated in the year prior to the start of our sample and are country-specific. As Laeven and Levine (2009) note, an individual firm's ownership structure is correlated with its industry average ownership structure. However, it is unlikely that the average industry ownership structure directly affects the syndicate structure of any particular loan of the borrowing firm except through the borrower's ownership structure. In the first stage regression (untabulated), the coefficients on the instruments are significantly different from zero at the $1 \%$ level, and the $F$-test confirms the validity of the instruments. We present the second stage results from the instrumental variables regressions in Table 5.

\section{[Insert Table 5 here]}

The estimates in Table 5 are consistent with our baseline results. Syndicate concentration and industry expertise are positively related to the control-ownership divergence at the borrowing firm, and foreign lender participation is negatively related to the divergence. After using instrumental variables to address the potential endogeneity concern, the effect of corporate ownership structure on bank loan syndicate structure remain strong and significant. The coefficients on the control-ownership wedge are larger in absolute magnitude than the corresponding coefficients from the OLS regressions and are all statistically significant at the $1 \%$ level. While it is impossible to completely solve the endogeneity problem, these test results alleviate the concern that endogeneity is likely to account for or bias our results.

\subsection{Factors influencing the wedge-syndicate structure relation}

${ }^{17}$ Laeven and Levine (2009) instrument for a bank's ownership structure using the average ownership structure variables of other banks. 
In this section, we examine the factors that influence the relation between the control-ownership divergence at the borrowing firm and the syndicate structure for the borrower's bank loans. Our goal is to shed light on the channels through which the tunneling and self-dealing risks and the associated monitoring needs induced by the control-ownership divergence at the borrowing firm can be exacerbated or mitigated. Specifically, we study the following five sets of factors: the lead arranger's reputation and lending relationship with the borrower, borrowing firm informational opacity, cash-flow rights dispersion across large owners, legal rights and institutions, and systemic financial crises. The intuition is that the effect of the control-ownership wedge on syndicate concentration and composition should be accentuated (attenuated) by mechanisms that increase (reduce) the credit risk and monitoring needs induced by large shareholders' excess control rights. Our empirical analyses in this section use the percentage of loan held by the lead arranger and the Herfindahl index as measures for syndicate concentration. We use the percentage of loan held by foreign lenders and the weighted-average syndicate industry expertise ratio as measures for syndicate composition. All of the results are robust to using the other measures for syndicate concentration and syndicate composition as in Table 3.

\subsubsection{Lead arranger's reputation and lending relationship with the borrowing firm}

The extant theoretical literature highlights the importance of lender reputation in lending behaviors and suggests that banks' concern with maintaining reputation will mitigate various moral hazard problems such as shirking (Chemmanur and Fulghieri, 1994). A good credit market reputation takes time to build up, and more reputable banks have more to lose from tarnished reputations. Hence, good reputation can serve as a bonding device that deters highly reputable banks from shirking their screening and monitoring responsibilities (Booth and Smith, 1986; Diamond, 1989; Chemmanur and Fulghieri, 1994). Moreover, the lead arranger's credit 
market reputation itself might signal and certify its skill in selecting, managing and monitoring the loans it syndicates (Demiroglu and James, 2010b). Therefore, we expect that the lead arranger's reputation will weaken the link between the control-ownership wedge and the syndicate structure. We test this hypothesis by including the measure for lead arranger reputation and its interaction with the control-ownership wedge in the baseline model. The results from this estimation are presented in the columns 1, 3, 5 and 7 of Table 6.

\section{[Insert Table 6 here]}

Our measure for lead arranger reputation is a dummy variable that equals one if the lead arranger is ranked as one of the top ten lenders in the syndicated loan market in terms of total amount lent for the period from 1996 to 2008. As the table shows, lead arranger reputation exerts a significant impact on syndicate structure. High lead arranger reputation is associated with a decrease in syndicate concentration and syndicate expertise and an increase in foreign lender participation. It is more interesting, however, that the coefficients on the interactive terms between wedge and reputation are statistically significant and bear the opposite signs of the corresponding coefficients on wedge. This indicates that the syndicate structure-wedge sensitivities are indeed lower for lead arrangers with good reputations. The effects are both statistically and economically significant. For instance, the coefficients in column 3 imply that, for a syndicate with a reputable lead arranger, a one-standard-deviation increase in the control-ownership wedge increases the average Herfindahl concentration index by approximately $43 \%$ less than for a syndicate without a reputable lead arranger.

The lead arranger's lending relationship with the borrowing firm might also affect the link between the control-ownership wedge and syndicate structure. In his survey paper, Boot (2000) summarizes that a relationship based on repeated lending to the same borrower facilitates monitoring in two ways. A close lending relationship helps overcome the information asymmetry and agency problems between the borrower and the lender. In addition, a bank is more willing to incur the cost of gathering borrower-specific information if it can be applied to multiple transactions in a long-lasting relationship than if it applies to a single 
transaction only. Moreover, its lending relationship with the borrowing firm can signal to the participant banks the lead arranger's ability, experience, cost advantage, and willingness in monitoring the borrower. As a result, we expect that a close lending relationship between the borrower and the lead arranger will tend to weaken the link between the control-ownership wedge and syndicate structure.

We test our hypothesis regarding the effect of lending relationships on the syndicate structure as follows. For each loan, we calculate the total amount of loans made by its lead arranger to the borrower during the previous five years, divided by the total amount of loans made to the borrower by all banks during the previous five years. ${ }^{18}$ This ratio is our measure of the closeness of the lead arranger's relationship with the borrowing firm. We re-estimate our baseline model including the lead arranger's lending relationship measure and its interaction with the control-ownership wedge. The results are presented in columns 2, 4, 6, and 8 of Table 6.

Like reputation, the lead arranger's lending relationship with the borrower not only affects syndicate structure directly, but also influences the relation between the wedge and syndicate structure. The coefficients on the interaction terms between lending relationship and control-ownership wedge are significant across all specifications and bear the opposite signs of the corresponding coefficients on the wedge. These results are consistent with our expectation that the lead arranger's lending relationship weakens the link between the control-ownership wedge and syndicate structure.

\subsubsection{Borrowing firm informational opacity}

18 Our results are robust to using windows other than five years. If there are multiple lead arrangers in a syndicate, the lead arranger's relationship measure is defined as the maximum relationship measure among all the lead arrangers in the syndicate. 
Informationally opaque firms are more difficult and costly to monitor than are transparent firms. The marginal cost to controlling shareholders of tunneling and self-dealing is lower at informationally opaque firms than at transparent firms. Therefore, the incentive and the likelihood for expropriation and other moral hazard activities by large shareholders should be greater at opaque firms. We expect that, as a result, the effect of control-ownership divergence on syndicate structure is strengthened in the presence of informational opacity.

We investigate the effect of borrower informational opacity on the link between the wedge and syndicate structure by including informational opacity measures and their interactions with the control-ownership wedge in our baseline model. We use several measures of informational opacity: borrower firm size (log assets), the number of analysts covering the borrowing firm, and a dummy variable indicating whether or not the borrower has a credit rating. In general, large firms with credit ratings and broad analyst coverage would tend to have low degrees of informational opacity. The results of the tests using these measures are presented in Table 7.

\section{[Insert Table 7 here]}

The first thing to note from Table 7 is that measures of borrower informational opacity largely have significant effects on syndicate structure. Borrower informational opacity is positively related to syndicate concentration and industry expertise and negatively related to foreign lender participation. After controlling for borrowing informational opacity, the effect of the control-ownership wedge on syndicate structure remains strong and significant. Moreover, the coefficients on the wedge-opacity interaction terms are statistically significant across all measures. Consistent with our baseline results, the control-ownership wedge increases the percentage of the loan held by the lead arranger as well as the overall syndicate concentration and industry expertise while reducing foreign lender participation in the syndicate. The effects of the wedge on syndicate structure are indeed stronger for informationally opaque firms than for relatively transparent ones. 


\subsubsection{Borrowing firm cash-flow rights dispersion across large owners}

Laeven and Levine (2008) study complex ownership structures and show that cash-flow rights dispersion across large owners is negatively related to firm valuation. In particular, their results suggest that the less evenly cash-flow rights are distributed between the largest and the second largest owners of the firm, the more difficult is enhanced monitoring. Under such circumstances, it is more likely than otherwise that the controlling shareholder has the incentive and the ability to divert corporate resources for private benefits. Therefore, we expect that the sensitivity of syndicate structure to the control-ownership wedge is strengthened by the dispersion of cash-flow rights across the borrower's large owners.

Following Laeven and Levine (2008), for each firm in our sample we identify whether there is a second largest ultimate owner with control rights greater than $10 \%$. If so, we calculate the cash-flow rights of this second largest owner. We then define the cash-flow rights dispersion across large owners as the difference between the cash-flow rights of the largest owner and the cash-flow rights of the second largest owner (Laeven and Levine, 2008). ${ }^{19}$

\section{[Insert Table 8 here]}

In Table 8, we report the results of re-estimating our baseline model adding the measure for cash-flow rights dispersion and its interaction with the control-ownership wedge as additional independent variables. The results in Table 8 show that, consistent with the predictions of Laeven and Levine (2008), the cash-flow rights dispersion between the two largest owners increases syndicate concentration and syndicate industry expertise and reduces foreign lender participation. More important, the significant coefficients on the interaction terms bearing the same signs as the coefficients on the wedge show that the syndicate concentration and syndicate

19 Following Laeven and Levine (2008), this variable equals zero if the firm does not have two controlling shareholders. 
composition measures are more sensitive to the control-ownership wedge when there is a high dispersion between the cash-flow rights of the two largest owners of the borrowing firm. As expected, cash-flow rights dispersion between large owners indeed strengthens the link between the wedge and syndicate structure.

\subsubsection{Legal rights and institutions}

In this section we examine how shareholder rights and credit information sharing systems affect the link between the control-ownership wedge and syndicate structure. Strong shareholder rights reduce tunneling and self-dealing incentives and protect minority shareholders against expropriation by controlling shareholders (Djankov et al., 2008). Information sharing agencies are institutional mechanisms established by creditors to reduce asymmetric information in lending. Information sharing among creditors improves creditors' knowledge of the characteristics and credit histories of borrowers and applicants (Barth et al., 2009). Information sharing also works as a post-lending disciplinary device by making it more difficult for borrowers with negative histories (e.g., late repayment, default, etc.) to get access to credit in the future (Padilla and Pagano, 1997; Houston et al., 2010). Therefore, the relation between the wedge and syndicate structure is likely to be weakened in countries with strong shareholder rights and in countries with good credit information sharing systems.

We use the anti-self-dealing index (Djankov et al., 2008) to proxy for shareholder protection from tunneling and self-dealing by controlling shareholders. This index is constructed from survey responses of attorneys regarding a hypothetical self-dealing case. These attorneys are affiliated with Lex Mundi law firms in 102 countries. Each country is assigned an index value. Higher values of the index indicate stronger shareholder protection. To proxy for credit information sharing, we use a dummy variable that equals one if an information sharing agency operates in the country of the borrower in the observation year and zero otherwise (Djankov et al., 2007; Doing Business Database, World Bank). In Table 9, we 
report the results for regressions that include the measures for shareholders rights and information sharing as well as their respective interactions with the control-ownership wedge. ${ }^{20}$

[Insert Table 9 here]

The results in Table 9 indicate that both shareholder rights and credit information sharing are negatively associated with syndicate concentration and syndicate industry expertise. They are positively associated with foreign lender participation. Also, both have qualitatively similar moderating effects on the link between the control-ownership wedge and syndicate structure. This highlights the important role that legal rights and institutions play in protecting investors, disciplining the market, and shaping bank lending activities (e.g., Esty and Megginson, 2003; Laeven and Levine, 2009; Houston et al. 2010).

\subsubsection{Financial crises}

In this section, we examine the relationship between corporate ownership structure and bank loan syndicate structure during financial crises. As previous studies suggest, financial crises represent relatively exogenous shocks that reduce the return on investment of all firms, thereby increasing the difficulty of investor monitoring and lowering the marginal cost of insiders' expropriation activities (Johnson et al., 2000b; Johnson and Mitton, 2003). We thus expect to observe a greater effect of the control-ownership divergence on syndicate structure during financial crises than during periods of normal financial market activity.

We define a dummy variable Financial crisis, which equals one if the country of the borrowing firm is undergoing a systemic financial crisis in the observation year. Financial crisis periods are identified in the International Monetary Fund (IMF) Banking Crisis

${ }^{20}$ We do not include the country fixed effects in these regressions because some of the key independent variables in this section (e.g., shareholder rights) are country-specific and time-invariant. 
Database. ${ }^{21}$ We add the Financial crisis dummy and its interaction with the control-ownership wedge to our baseline model and present the estimation results in Table 10.

[Insert Table 10 here]

The estimates from Table 10 show that loan syndicates during financial crises are more concentrated, composed of fewer foreign lenders and of lenders with greater industry lending expertise than are syndicates during periods of normal financial market activity. More important, the coefficients on the interaction terms between the wedge and the crisis dummy indicate that the wedge-syndicate structure sensitivities increase during crisis times. Borrowing firm ownership structure affects the concentration and composition of loan syndicates even during normal times. The estimated coefficients on the wedge variable are statistically significant across all specifications. The effects, however, are amplified for the borrowers in countries experiencing financial crises.

\section{Conclusion}

In this paper, we explore how ownership structures of borrowing firms influence the financing arrangements for their syndicated loans. Using a novel data set comprised of borrowing firms across 22 countries from 1996 to 2008, we find strong evidence that the divergence between the control rights and cash-flow rights of the largest ultimate owner of a borrowing firm significantly affects the structure of its syndicated loans. When large shareholders of a borrowing firm have control rights that exceed their cash-flow rights, lenders concentrate the loan syndicate and the lead arranger retains a relatively large portion of the loan. Moreover, the syndicate tends to be comprised of lenders with more lending expertise related to the borrowing firm's industry and of domestic lenders that are geographically close to the

${ }^{21}$ The Banking Crisis Database provides a comprehensive coverage of systemic banking and financial crisis episodes in 93 countries from 1972 to 2008 (Honohan and Laeven, 2005). 
borrowing firm. Further analyses indicate that the effect of the control-ownership wedge on syndicate concentration and composition is particularly pronounced for firms that are informationally opaque, firms that have a high dispersion of cash-flow rights across large owners, and firms in countries undergoing financial crises. On the other hand, the relation between the control-ownership divergence and loan syndicate structure is weakened if the lead arranger has a favorable reputation and a close lending relationship with the borrowing firm. This relation is also weakened by strong legal protection for shareholders and the presence of good credit information sharing systems. These results contribute to our understanding of how the self-dealing activities and the associated credit risk induced by the control-ownership divergence can be mitigated and how lending institutions structure financing arrangements when effective monitoring is most important. 


\section{References}

Barth, J., Lin, C., Lin, P., Song, F., 2009. Corruption in bank lending to firms: cross-country micro evidence on the beneficial role of competition and information sharing. Journal of Financial Economics 91, 361-388.

Beck, T., Demirgüç-Kunt, A., Levine, R., 2006. Bank concentration, competition, and crises: First results. Journal of Banking and Finance 30, 1581-1603.

Bolton, P., Scharfstein, D., 1996. Optimal debt contracts and the number of creditors. Journal of Political Economy 104, 1-25.

Boot, A., 2000. Relationship banking: What do we know? Journal of Financial Intermediation 9, $7-25$.

Booth, J.R., Smith, R.L., 1986. Capital raising, underwriting, and the certification hypothesis. Journal of Financial Economics 15, 261-281.

Brunner, A., Krahnen, J., 2008. Multiple lenders and corporate distress: Evidence on debt restructuring. Review of Economic Studies 75, 415-442.

Campello, M., Lin, C., Ma, Y., Zou, H., 2010. The real and financial implications of corporate hedging. Journal of Finance, forthcoming.

Chemmanur, T., Fulghieri, P., 1994. Reputation, renegotiation, and the choice between bank loans and public traded debt. Review of Financial Studies 7, 475-506.

Chui, M., Domanski, D., Kugler, P., Shek, J., 2010. The collapse of international bank finance during the crisis: Evidence from syndicated loan markets. BIS Quarterly Review, September 2010, 39-49.

Claessens, S., Djankov, S., Lang, L.H.P., 2000. The separation of ownership and control in East Asian corporations. Journal of Financial Economics 58, 81-112.

Claessens, S., Djankov, S., Fan, J., Lang, L.H.P., 2002. Disentangling the incentive and entrenchment effects of large shareholdings. Journal of Finance 57, 2741-2771.

Claessens, S., Laeven, L., 2003. Financial development, property rights, and growth. Journal of Finance 58, 2401-2436. 
Demiroglu, C., James, C., 2010a. The information content of bank loan covenants. Review of Financial Studies, forthcoming.

Demiroglu, C., James, C., 2010b. The role of private equity group reputation in LBO financing. Journal of Financial Economics 96, 306-330.

Diamond, D., 1984. Financial intermediation and delegated monitoring. Review of Economic Studies 51, 393-414.

Diamond, D., 1989. Reputation acquisition in debt markets. Journal of Political Economy 97, $828-862$.

Djankov, S., McLeish, C., Shleifer, A., 2007. Private credit in 129 countries. Journal of Financial Economics 84, 299-329.

Djankov, S., La Porta, R., López-de-Silanes, F., Shleifer, A., 2008. The law and economics of self-dealing. Journal of Financial Economics 88, 430-465.

Esty, B., 2001. Structuring loan syndicates: A case study of the Hong Kong Disneyland project loan. Journal of Applied Corporate Finance 14, 80-95.

Esty, B., Megginson, W., 2003. Creditor rights, enforcement, and debt ownership structure: Evidence from the global syndicated loan market. Journal of Financial and Quantitative Analysis 38, 37-59.

Esty, B., 2004. When do foreign banks finance domestic projects? New evidence on the importance of legal and financial systems. Mimeo, Harvard Business School.

Faccio, M., Lang Larry H.P., 2002. The ultimate ownership of Western European corporations. Journal of Financial Economics 65, 365-395.

Friedman, E., Johnson, S., Mitton, T., 2003. Propping and tunneling. Journal of Comparative Economics 31, 732-750.

Gertner, R., Scharfstein, D., 1991. A theory of workouts and the effects of reorganization law. Journal of Finance 46, 1189-1222.

Gompers, P., Ishii, J., Metrick, A., 2010. Extreme governance: An analysis of dual-class firms in the United States. Review of Financial Studies 23, 1051-1088.

Goplan, R., Nanda, V., Yerramilli, V., 2010. Does poor performance damage the reputation of 
financial intermediaries? Evidence from the loan syndication market. Journal of Finance, forthcoming.

Graham, J., Li, S., Qiu, J., 2008. Corporate misreporting and bank loan contracting. Journal of Financial Economics 89, 44-61.

Holmstrom, B., Tirole, J., 1997. Financial intermediation, loanable funds, and the real sector. Quarterly Journal of Economics 112, 663-691.

Honohan, P., Laeven, L., 2005. Systemic Financial Distress: Containment and Resolution. Cambridge University Press, Cambridge, UK.

Houston, J., Lin, C., Lin, P., Ma, Y., 2010. Creditor rights, information sharing and bank risk taking. Journal of Financial Economics 96, 485-512.

Ivashina, V., 2009. Asymmetric information effects on loan spreads. Journal of Financial Economics 92, 300-319.

Johnson, S., La Porta, R., López-de-Silanes, F., Shleifer, A., 2000a. Tunneling. American Economic Review 90, 22-27.

Johnson, S., Boone, P., Breach, A., Friedman, E., 2000b. Corporate governance in the Asian financial crisis. Journal of Financial Economic 58, 141-186.

Johnson, S., Mitton, T., 2003. Cronyism and Capital Controls: Evidence from Malaysia. Journal of Financial Economics 67, 351-382.

La Porta, R., López-de-Silanes, F., Shleifer, A., 1999. Corporate ownership around the world. Journal of Finance 54, 471-517.

Laeven, L., Levine, R., 2007. Is there a diversification discount in financial conglomerates? Journal of Financial Economics 85, 331-367.

Laeven, L., Levine, R., 2008. Complex ownership structures and corporate valuations. Review of Financial Studies 21, 579-604.

Laeven, L., Levine, R., 2009. Bank governance, regulation and risk taking. Journal of Financial Economics 93, 259-275.

Lin, C., Ma, Y., Malatesta, P., Xuan, Y., 2011. Ownership structure and the cost of corporate borrowing. Journal of Financial Economics 100, 1-23. 
Martin, S., 2009. Loan participations and syndications: Structure selection and documentation to achieve your goals. Ohio Banking Law, Summer 2009, 9-10.

McCahey, J., 2003. Loan participations: Participant's claims against lead lenders. Commercial and Business Litigation Journal, Summer 2003, 11-14.

Padilla, A., Pagano, M., 1997. Endogenous communication among lenders, and entrepreneurial incentives. Review of Financial Studies 10, 205-236.

Qian, J., Strahan, P., 2007. How laws and institutions shape financial contracts: the case of bank loans. Journal of Finance 62, 2803-2834.

Raddatz, C., 2006. Liquidity needs and vulnerability to financial underdevelopment. Journal of Financial Economics 80, 677-722.

Rajan, R., Zingales, L., 1998. Financial dependence and growth. American Economic Review 88, 559-586.

Rhodes, T., Clark, K., Campbell, M., 2000. Syndicated Lending: Practice and Documentation, Euromoney, London, UK.

Shleifer, A., Vishny, R., 1997. A survey of corporate governance. Journal of Finance 52, $737-783$.

Stein, J., 2002. Information production and capital allocation: Decentralized versus hierarchical firms. Journal of Finance 57, 1891-1922.

Sufi, A., 2007. Information asymmetry and financing arrangements: Evidence from syndicated loans. Journal of Finance 62, 629-668.

Wight, R., Cooke, W., Milbank, R., 2009. The LSTA (Loan Syndications and Trading Association)'s Complete Credit Agreement Guide. McGraw-Hill. 


\section{Table 1 Definitions of variables}

This table provides detailed definitions for all the variables used in the paper.

Variable names $\quad$ Variable definitions

\section{Syndicate concentration}

Total number of lenders

Amount of loan kept by lead arranger

Percentage of loan kept by

lead arranger

Herfindahl index of lenders'

shares

\section{Syndicate composition}

Number of foreign lenders

Percentage of loan held by

foreign lenders

Total syndicate industry

expertise

Average syndicate industry expertise

\section{Borrower ownership}

Control-ownership wedge

Cash-flow rights

Cash-flow rights dispersion

across large owners

\section{Borrower characteristics}

Leverage

Tangibility

Log assets

Profitability

Cash-flow volatility

S\&P rating

No rating dummy

Q

Number of analysts
The total number of lenders in the syndicate

The dollar amount of the loan kept by the lead arranger. If the syndicate has more than one lead arranger, this is the total amount of the loan kept by all the lead arrangers.

The percentage of the loan kept by the lead arranger. If the syndicate has more than one lead arranger, this is the total percentage of the loan kept by all the lead arrangers.

The Herfindahl index of lenders' shares in the loan, computed as the sum of the squares of each lender' share in the loan

The total number of foreign lenders in the syndicate

The total percentage of the loan held by all foreign lenders

The sum of the industry expertise ratios of all the lenders in the syndicate. The industry experience ratio of a lender is defined as the total amount of loans it has made over the past five years in the three-digit SIC industry that the borrower belongs to, divided by the total amount of loans issued in the same industry over the same period by all the lenders in Dealscan.

The weighted average of the industry expertise ratios of all the lenders in the syndicate, with each lender's share in the loan as its weight. The industry experience ratio of a lender is defined as the total amount of loans it has made over the past five years in the three-digit SIC industry that the borrower belongs to, divided by the total amount of loans issued in the same industry over the same period by all the lenders in Dealscan.

The difference between the control rights and cash-flow rights of the largest ultimate owner of the firm

The cash-flow rights of the largest ultimate owner of the firm

The difference between the cash-flow rights of the largest owner and the cash-flow rights of the second largest owner (Laeven and Levine, 2008)

The sum of long-term debt and debt in current liabilities, divided by total assets

Net property, plant, and equipment, divided by total assets

The natural log of total assets measured in millions of US dollars

Net income, divided by total assets

The standard deviation of quarterly cash flows from operations over the four fiscal years prior to the loan initiation year, scaled by the sum of long-term debt and debt in current liabilities

The S\&P firm credit rating, converted to an index from one to seven as follows: $1=$ Aaa, $2=\mathrm{Aa}, 3=\mathrm{A}, 4=\mathrm{Bbb}, 5=\mathrm{Bb}, 6=\mathrm{B}$ or worse, and $7=$ no rating

A dummy variable that equals one if the firm does not have an S\&P credit rating and zero otherwise

The sum of market value of equity plus the book value of debt, divided by total assets. Market value of equity equals price per share times total number of shares outstanding. Book value of debt equals total assets minus book value of equity.

The total number of stock analysts covering the firm 


\section{Table 1 Definitions of variables}

(Continued)

\begin{tabular}{ll}
\hline $\begin{array}{l}\text { Variable names } \\
\text { Loan characteristics } \\
\text { Performance pricing dummy }\end{array}$ & $\begin{array}{l}\text { Aariable definitions } \\
\text { otherwise }\end{array}$ \\
$\begin{array}{l}\text { A dummy variable that equals one if the loan is a term loan and zero otherwise } \\
\text { Log loan size }\end{array}$ & $\begin{array}{l}\text { The natural log of the loan amount measured in millions of US dollars } \\
\text { Log loan maturity }\end{array}$ \\
Toan purpose dummies & $\begin{array}{l}\text { Dummy vatural log of the loan maturity measured in days } \\
\text { expenditure, corporate purposes, refinancing, working capital, and others }\end{array}$
\end{tabular}

Lead arranger characteristics

Top ten lender

Lending relationship with borrower

\section{Macroeconomic factors}

Sovereign risk rating

Private credit to GDP

Log GDP per capita

Anti-self-dealing

Credit information sharing

Financial crisis
A dummy variable that equals one if the lead arranger is ranked as one of the top ten lenders in the syndicated loan market in terms of amount lent for the period from 1996 to 2008 and zero otherwise

The amount of loans the lead arranger has made to the borrower in the previous five years, divided by the total amount of loans made to the borrower by all banks in the previous five years

Moody's rating on the long-term sovereign (government) bonds for the borrower's country (denominated in US dollars), converted into an index from one to six as follows: $1=\mathrm{Aaa}, 2=\mathrm{Aa}, 3=\mathrm{A}, 4=\mathrm{Bbb}, 5=\mathrm{Bb}$, and $6=\mathrm{B}$ or worse

The private credit by commercial banks and other financial institutions, divided by GDP The natural log of the real GDP per capita in US dollars (USD)

An index constructed based on the survey of a hypothetical self-dealing case among attorneys from Lex Mundi law firms in 102 countries (Djankov et al., 2008). Higher values of the index indicate stronger shareholder protection against self-dealing by controlling shareholders.

A dummy variable that equals one if an information sharing agency operates in the country of the borrower in the observation year and zero otherwise (Djankov et al., 2007) A dummy variable that equals one if the country of the borrower is undergoing a financial crisis in the observation year and zero otherwise, as identified in the International Monetary Fund (IMF) Banking Crisis Database 
Table 2 Summary statistics

This table presents the mean, standard deviation (STD), and number of observations $(N)$ for all the variables used in the paper. Definitions of all the variables are reported in Table 1.

Variable names

Syndicate concentration

Total number of lenders

Amount of loan kept by lead arranger (\$MM)

Percentage of loan kept by lead arranger (\%)

Herfindahl index of lenders' shares

Syndicate composition

Number of foreign lenders

Percentage of loan kept by foreign lenders (\%)

Total syndicate industry expertise (\%)

Average syndicate industry expertise (\%)

Borrower ownership

Control-ownership wedge

Cash-flow rights

Cash-flow rights dispersion between large owners

Borrower characteristics

Leverage

Tangibility

Total assets (\$MM)

Profitability

Cash-flow volatility

S\&P rating

No rating dummy

$Q$

Number of analysts

Loan characteristics

Performance pricing dummy

Term loan dummy

Loan size (\$MM)

Loan maturity (days)

Lead arranger characteristics

Top 10 lender

Lending relationship with the borrower (\%)

Macroeconomic factors

Sovereign risk rating

Private credit to GDP

GDP per capita

Anti-self-dealing

Credit information sharing

Financial crisis

Mean

7.974

138.871

57.282

0.257

4.756

58.235

1.622

0.564

0.064

0.270

0.178

0.333

0.326

4665

0.090

0.735

1.590

0.277

1.264

11.787

0.059

0.467

362

1582

0.570

13.703

1.692

1.300

22689

0.618

0.912

0.231
STD $N$

8.514

14,350

8,282

8,282

8,282

0.200

6.765

14,350

43.265

8,282

7.138

14,350

3.146

8,282

14,350

14,350

14,350

0.171

0.293

14,350

14,350

14,350

14,350

14,350

14,350

14,350

14,350

14,350

11.106

14,350

14,350

14,350

14,350

1042

0.495

14,350

14,350

25.698

14,350

14,350

14,350

14,350

14,350

14,350 


\section{Table 3 The effect of the control-ownership wedge on syndicate structure}

This table presents the OLS regression results on the effect of the control-ownership wedge on syndicate structure. The dependent variables are the total number of lenders

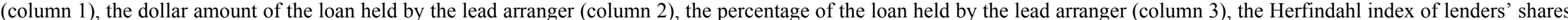

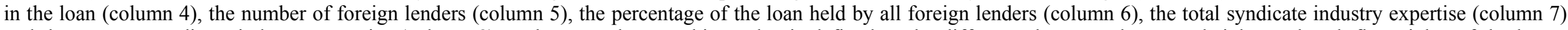

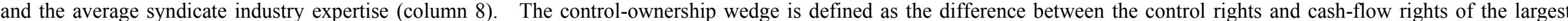

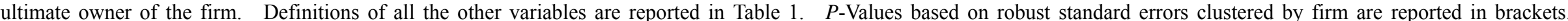
Significance at the $10 \%, 5 \%$, and $1 \%$ level is indicated by $* * *$, and $* * *$, respectively.

\begin{tabular}{|c|c|c|c|c|c|c|c|c|}
\hline & (1) & (2) & (3) & (4) & (5) & (6) & (7) & (8) \\
\hline & \multicolumn{4}{|c|}{ Syndicate Concentration } & \multicolumn{4}{|c|}{ Syndicate Composition } \\
\hline & $\begin{array}{l}\text { Total number } \\
\text { of lenders }\end{array}$ & $\begin{array}{l}\text { Amount of loan } \\
\text { held by lead } \\
\text { arranger }(\$ M M)\end{array}$ & $\begin{array}{l}\text { Percentage of } \\
\text { loan held by lead } \\
\text { arrangers (\%) }\end{array}$ & $\begin{array}{l}\text { Herfindahl index } \\
\text { of lenders' shares }\end{array}$ & $\begin{array}{l}\text { Number of } \\
\text { foreign lenders }\end{array}$ & $\begin{array}{l}\text { Percentage of loan } \\
\text { held by foreign } \\
\text { lenders }(\%)\end{array}$ & $\begin{array}{l}\text { Total syndicate } \\
\text { industry expertise } \\
(\%)\end{array}$ & $\begin{array}{l}\text { Average syndicate } \\
\text { industry expertise } \\
(\%)\end{array}$ \\
\hline \multirow[t]{2}{*}{ Control-ownership wedge } & -15.267 & 173.565 & 63.225 & 0.401 & -8.184 & -99.121 & 1.930 & 0.826 \\
\hline & {$[0.026]^{* *}$} & {$[0.023]^{* *}$} & {$[0.008]^{* * *}$} & {$[0.007]^{* * *}$} & {$[0.016]^{* *}$} & {$[0.008]^{* * *}$} & {$[0.006]^{* * *}$} & {$[0.003]^{* * *}$} \\
\hline \multirow[t]{2}{*}{ Cash-flow rights } & 2.419 & -45.038 & -17.361 & -0.095 & 1.526 & 16.776 & -0.822 & -0.291 \\
\hline & {$[0.015]^{* *}$} & {$[0.022]^{* *}$} & {$[0.021]^{* *}$} & {$[0.022]^{* *}$} & {$[0.073]^{*}$} & {$[0.024]^{* *}$} & {$[0.012]^{* *}$} & {$[0.283]$} \\
\hline \multirow[t]{2}{*}{ Leverage } & -4.648 & 40.875 & 22.266 & 0.075 & -3.249 & -31.465 & 0.981 & 0.288 \\
\hline & [0.409] & {$[0.486]$} & {$[0.071]^{*}$} & {$[0.374]$} & {$[0.366]$} & {$[0.053]^{*}$} & {$[0.316]$} & {$[0.452]$} \\
\hline \multirow[t]{2}{*}{ Tangibility } & 2.215 & -36.322 & -14.589 & -0.041 & 1.148 & 11.423 & -0.339 & -0.119 \\
\hline & {$[0.092]^{*}$} & {$[0.011]^{* *}$} & {$[0.176]$} & {$[0.032]^{* *}$} & {$[0.148]$} & {$[0.014]^{* *}$} & {$[0.022]^{* *}$} & {$[0.345]$} \\
\hline \multirow[t]{2}{*}{ Log assets } & 0.053 & -2.539 & -0.819 & -0.003 & 0.034 & 0.489 & -0.037 & -0.054 \\
\hline & {$[0.032]^{* *}$} & {$[0.012]^{* *}$} & {$[0.022]^{* *}$} & {$[0.154]$} & {$[0.075]^{*}$} & {$[0.081]^{*}$} & {$[0.032]^{* *}$} & {$[0.033]^{* *}$} \\
\hline \multirow[t]{2}{*}{ Profitability } & 5.228 & -229.533 & -104.451 & -0.563 & 1.457 & 18.137 & -2.572 & -1.215 \\
\hline & {$[0.254]$} & {$[0.146]$} & {$[0.046]^{* *}$} & {$[0.043]^{* *}$} & {$[0.247]$} & {$[0.062]^{*}$} & {$[0.246]$} & {$[0.264]$} \\
\hline \multirow[t]{2}{*}{ Cash-flow volatility } & -0.240 & 5.385 & 2.323 & 0.009 & -0.040 & -0.223 & 0.043 & 0.024 \\
\hline & {$[0.012]^{* *}$} & {$[0.394]$} & {$[0.124]$} & {$[0.021]^{* *}$} & {$[0.032]^{* *}$} & {$[0.053]^{*}$} & {$[0.033]^{* *}$} & {$[0.120]$} \\
\hline \multirow[t]{2}{*}{$\mathrm{S} \& \mathrm{P}$ rating } & -0.124 & 19.373 & 7.167 & 0.028 & -0.159 & -2.192 & 0.229 & 0.078 \\
\hline & {$[0.033]^{* *}$} & {$[0.022]^{* *}$} & {$[0.031]^{* *}$} & {$[0.069]^{*}$} & {$[0.044]^{* *}$} & {$[0.024] * *$} & {$[0.023]^{* *}$} & {$[0.012]^{* *}$} \\
\hline
\end{tabular}

(Continued on the next page) 
Table 3 The effect of the control-ownership wedge on syndicate structure

(Continued)

\begin{tabular}{|c|c|c|c|c|c|c|c|c|}
\hline & (1) & $(2)$ & (3) & (4) & (5) & $(6)$ & (7) & $(8)$ \\
\hline & \multicolumn{4}{|c|}{ Syndicate Concentration } & \multicolumn{4}{|c|}{ Syndicate Composition } \\
\hline & $\begin{array}{l}\text { Total number } \\
\text { of lenders }\end{array}$ & $\begin{array}{l}\text { Amount of loan } \\
\text { held by lead } \\
\text { arranger }(\$ M M)\end{array}$ & $\begin{array}{l}\text { Percentage of } \\
\text { loan held by lead } \\
\text { arrangers }(\%)\end{array}$ & $\begin{array}{l}\text { Herfindahl index } \\
\text { of lenders' shares }\end{array}$ & $\begin{array}{l}\text { Number of } \\
\text { foreign lenders }\end{array}$ & $\begin{array}{l}\text { Percentage of loan } \\
\text { held by foreign } \\
\text { lenders }(\%)\end{array}$ & $\begin{array}{l}\text { Total syndicate } \\
\text { industry expertise } \\
(\%)\end{array}$ & $\begin{array}{l}\text { Average syndicate } \\
\text { industry expertise } \\
(\%)\end{array}$ \\
\hline \multirow[t]{2}{*}{ No rating dummy } & -1.059 & 21.763 & 6.358 & 0.031 & -1.428 & -15.397 & 0.267 & 0.108 \\
\hline & {$[0.033]^{* *}$} & {$[0.155]$} & {$[0.089]^{*}$} & {$[0.020]^{* *}$} & {$[0.031]^{* *}$} & {$[0.033]^{* *}$} & {$[0.023]^{* *}$} & {$[0.014]^{* *}$} \\
\hline \multirow[t]{2}{*}{$Q$} & 0.735 & -21.063 & -3.641 & -0.018 & 0.189 & 1.593 & 0.226 & 0.098 \\
\hline & {$[0.184]$} & {$[0.443]$} & {$[0.179]$} & {$[0.439]$} & {$[0.146]$} & {$[0.544]$} & {$[0.461]$} & {$[0.144]$} \\
\hline \multirow[t]{2}{*}{ Performance pricing dummy } & 1.630 & -12.820 & -5.315 & -0.024 & 1.080 & 11.886 & -0.261 & -0.083 \\
\hline & {$[0.014]^{* *}$} & {$[0.276]$} & {$[0.012]^{* *}$} & {$[0.075]^{*}$} & {$[0.012]^{* *}$} & {$[0.035]^{* *}$} & {$[0.012]^{* *}$} & {$[0.060]^{*}$} \\
\hline \multirow[t]{2}{*}{ Term loan dummy } & -1.891 & 32.072 & 13.883 & 0.054 & -1.163 & -7.621 & 0.340 & 0.114 \\
\hline & {$[0.129]$} & {$[0.269]$} & {$[0.128]$} & {$[0.031]^{* *}$} & {$[0.030]^{* *}$} & {$[0.227]$} & {$[0.062]^{*}$} & {$[0.012]^{* *}$} \\
\hline \multirow[t]{2}{*}{ Log loan size } & 2.213 & -14.891 & -4.908 & -0.024 & 0.739 & 8.501 & 0.136 & 0.056 \\
\hline & {$[0.031]^{* *}$} & {$[0.059]^{*}$} & {$[0.023]^{* *}$} & {$[0.020]^{* *}$} & {$[0.031]^{* *}$} & {$[0.068]^{*}$} & {$[0.026]^{* *}$} & {$[0.166]$} \\
\hline \multirow[t]{2}{*}{ Log loan maturity } & 1.307 & -28.369 & -11.939 & -0.053 & -0.524 & -7.080 & 0.313 & 0.137 \\
\hline & {$[0.041]^{* *}$} & {$[0.039]^{* *}$} & {$[0.012]^{* *}$} & {$[0.074]^{*}$} & {$[0.012]^{* *}$} & {$[0.054]^{*}$} & {$[0.020]^{* *}$} & {$[0.032]^{* *}$} \\
\hline \multirow[t]{2}{*}{ Sovereign risk rating } & -1.222 & 19.940 & 11.863 & 0.035 & -0.981 & -12.877 & 0.247 & 0.082 \\
\hline & {$[0.063]^{*}$} & {$[0.161]$} & {$[0.065]^{*}$} & {$[0.407]$} & {$[0.136]$} & {$[0.186]$} & {$[0.156]$} & {$[0.140]$} \\
\hline \multirow[t]{2}{*}{ Private credit to GDP } & 1.144 & -11.684 & -4.530 & -0.021 & 1.304 & 16.786 & 0.256 & 0.079 \\
\hline & {$[0.023]^{* *}$} & {$[0.137]$} & {$[0.075]^{*}$} & {$[0.056]^{*}$} & {$[0.019]^{* *}$} & {$[0.175]$} & {$[0.016]^{* *}$} & {$[0.012]^{* *}$} \\
\hline \multirow[t]{2}{*}{ Log GDP per capita } & 1.970 & -31.947 & -15.184 & -0.048 & 0.219 & 2.908 & -0.304 & -0.086 \\
\hline & {$[0.070]^{*}$} & {$[0.530]$} & {$[0.078]^{*}$} & {$[0.271]$} & {$[0.389]$} & {$[0.252]$} & {$[0.464]$} & {$[0.127]$} \\
\hline Loan purpose dummies & Yes & Yes & Yes & Yes & Yes & Yes & Yes & Yes \\
\hline Country effects & Yes & Yes & Yes & Yes & Yes & Yes & Yes & Yes \\
\hline Industry effects & Yes & Yes & Yes & Yes & Yes & Yes & Yes & Yes \\
\hline Time effects & Yes & Yes & Yes & Yes & Yes & Yes & Yes & Yes \\
\hline Number of observations & 14,350 & 8,282 & 8,282 & 8,282 & 14,350 & 8,282 & 14,350 & 8,282 \\
\hline Number of firms & 3,056 & 2,167 & 2,167 & 2,167 & 3,056 & 2,167 & 3,056 & 2,167 \\
\hline Adjusted $\mathrm{R}^{2}$ & 0.424 & 0.252 & 0.351 & 0.156 & 0.425 & 0.458 & 0.161 & 0.187 \\
\hline
\end{tabular}




\section{Table 4 Robustness: Country $\times$ year and industry $\times$ year fixed effects}

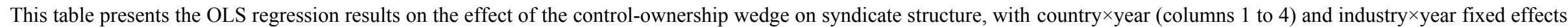

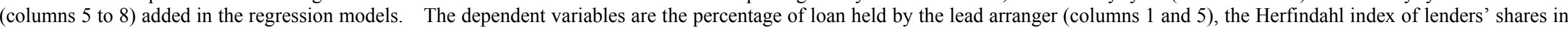

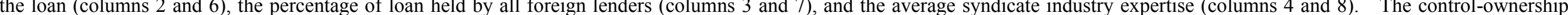

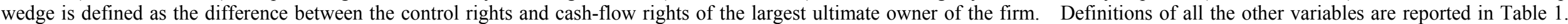

$P$-Values based on robust standard errors clustered by firm are reported in brackets. Significance at the $10 \%, 5 \%$, and $1 \%$ level is indicated by $* * *$, and $* * *$, respectively.

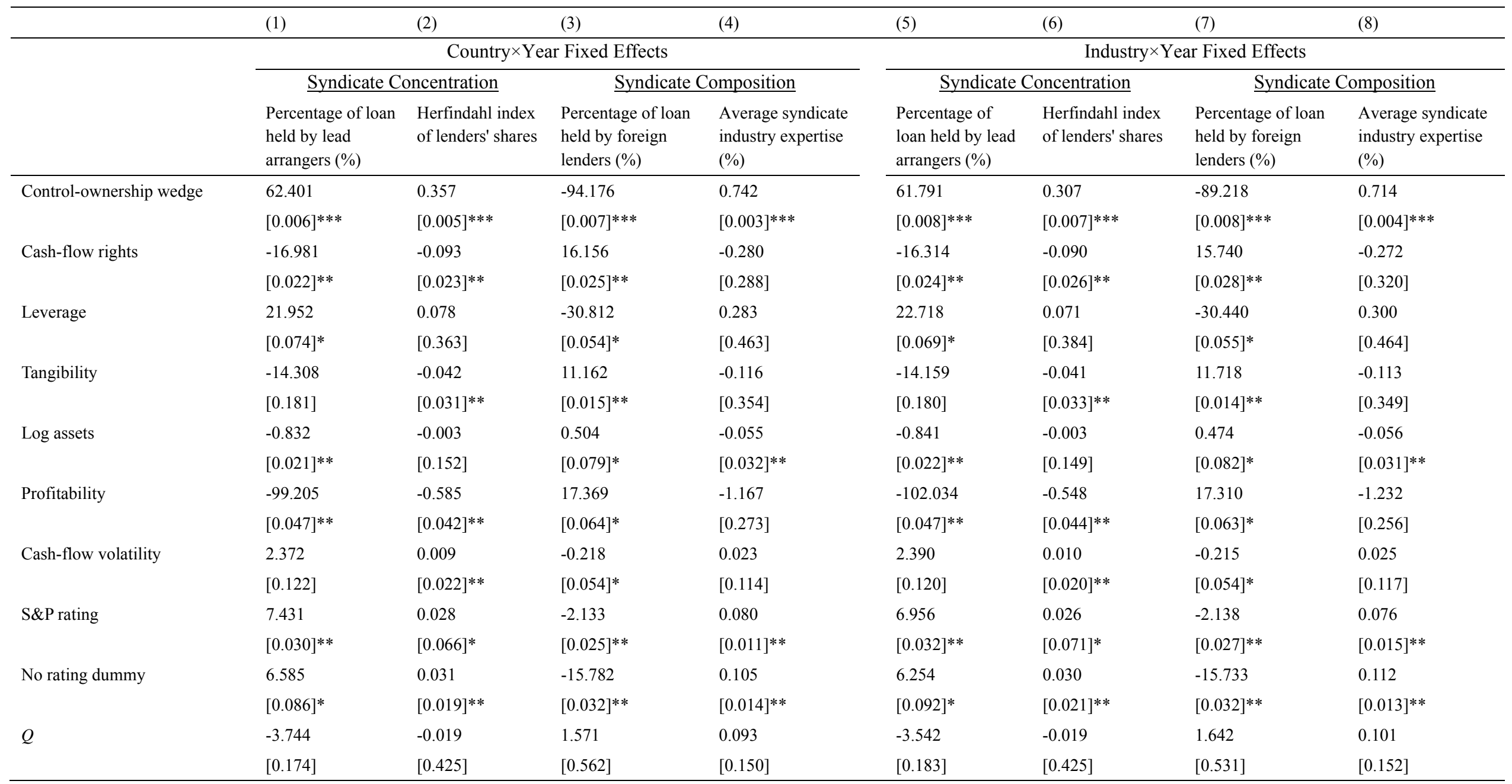

(Continued on the next page) 
Table 4 Robustness: Country $\times$ year and industry $\times$ year fixed effects

(Continued)

\begin{tabular}{|c|c|c|c|c|c|c|c|c|}
\hline & $(1)$ & $(2)$ & $(3)$ & $(4)$ & $(5)$ & $(6)$ & $(7)$ & $(8)$ \\
\hline & \multicolumn{4}{|c|}{ Interactions of country effects and time effects } & \multicolumn{4}{|c|}{ Interactions of industry effects and time effects } \\
\hline & \multicolumn{2}{|c|}{ Syndicate Concentration } & \multicolumn{2}{|c|}{ Syndicate Composition } & \multicolumn{2}{|c|}{ Syndicate Concentration } & \multicolumn{2}{|c|}{ Syndicate Composition } \\
\hline Performance pricing dummy & -5.055 & -0.025 & 11.460 & -0.085 & -5.134 & -0.025 & 12.087 & -0.086 \\
\hline \multirow[t]{2}{*}{ Term loan dummy } & 13.355 & 0.053 & -7.434 & 0.108 & 13.714 & 0.051 & -7.479 & 0.111 \\
\hline & {$[0.125]$} & {$[0.030]^{* *}$} & {$[0.232]$} & {$[0.012]^{* *}$} & {$[0.126]$} & {$[0.032]^{* *}$} & {$[0.232]$} & {$[0.012]^{* *}$} \\
\hline \multirow[t]{2}{*}{ Log loan size } & -4.747 & -0.025 & 8.395 & 0.054 & -4.688 & -0.025 & 8.611 & 0.055 \\
\hline & {$[0.022]^{* *}$} & {$[0.019]^{* *}$} & {$[0.066]^{*}$} & {$[0.168]$} & {$[0.022]^{* *}$} & {$[0.020]^{* *}$} & {$[0.066]^{*}$} & {$[0.170]$} \\
\hline \multirow[t]{2}{*}{ Log loan maturity } & -12.379 & -0.054 & -6.765 & 0.142 & -11.382 & -0.052 & -7.241 & 0.139 \\
\hline & {$[0.012]^{* *}$} & {$[0.071]^{*}$} & {$[0.055]^{*}$} & {$[0.030]^{* *}$} & {$[0.012]^{* *}$} & {$[0.072]^{*}$} & {$[0.053]^{*}$} & {$[0.031]^{* *}$} \\
\hline Sovereign risk rating & & & & & {$[0.065]^{*}$} & {$[0.394]$} & {$[0.184]$} & {$[0.144]$} \\
\hline \multirow[t]{2}{*}{ Private credit to GDP } & & & & & -4.601 & -0.022 & 16.161 & 0.081 \\
\hline & & & & & {$[0.073]^{*}$} & {$[0.054]^{*}$} & {$[0.182]$} & {$[0.012]^{* *}$} \\
\hline \multirow[t]{2}{*}{ Log GDP per capita } & & & & & -15.687 & -0.049 & 2.823 & -0.083 \\
\hline & & & & & {$[0.075]^{*}$} & {$[0.279]$} & {$[0.261]$} & {$[0.131]$} \\
\hline Loan purpose dummies & Yes & Yes & Yes & Yes & Yes & Yes & Yes & Yes \\
\hline Country effects $\mathrm{x}$ time effects & Yes & Yes & Yes & Yes & - & - & - & - \\
\hline Country effects & - & - & - & - & Yes & Yes & Yes & Yes \\
\hline Industry effects $\mathrm{x}$ time effects & - & - & - & - & Yes & Yes & Yes & Yes \\
\hline Industry effects & Yes & Yes & Yes & Yes & - & - & - & - \\
\hline Number of observations & 14,350 & 8,282 & 8,282 & 8,282 & 14,350 & 8,282 & 14,350 & 8,282 \\
\hline Number of firms & 3,056 & 2,167 & 2,167 & 2,167 & 3,056 & 2,167 & 3,056 & 2,167 \\
\hline
\end{tabular}




\section{Table 5 Instrumental variables estimation}

This table presents the results of instrumental variables estimations of the effect of the control-ownership wedge on syndicate structure. The dependent variables are the percentage of loan held by the lead arranger (column 1), the Herfindahl index of lenders' shares in the loan (column 2), the percentage of loan held by all foreign lenders (column 3), and the average syndicate industry expertise (column 4). The control-ownership wedge is defined as the difference between the control rights and cash-flow rights of the largest ultimate owner of the firm. The instruments for the control-ownership wedge and cash-flow rights are the initial industry average wedge and the initial industry average cash-flow rights, respectively. Definitions of all the other variables are reported in Table $1 . P$-Values based on robust standard errors clustered by firm are reported in brackets. Significance at the $10 \%, 5 \%$, and $1 \%$ level is indicated by $*, * *$, and $* * *$, respectively.

\begin{tabular}{|c|c|c|c|c|}
\hline & (1) & (2) & (3) & (4) \\
\hline & \multicolumn{2}{|c|}{ Syndicate Concentration } & \multicolumn{2}{|c|}{ Syndicate Composition } \\
\hline & $\begin{array}{l}\text { Percentage of loan } \\
\text { held by lead } \\
\text { arranger (\%) }\end{array}$ & $\begin{array}{l}\text { Herfindahl } \\
\text { index of } \\
\text { lenders' shares }\end{array}$ & $\begin{array}{l}\text { Percentage of loan } \\
\text { held by foreign } \\
\text { lenders (\%) }\end{array}$ & $\begin{array}{l}\text { Average Syndicate } \\
\text { Industry expertise } \\
(\%)\end{array}$ \\
\hline \multirow[t]{2}{*}{ Control-ownership wedge } & 106.594 & 0.597 & -138.738 & 1.217 \\
\hline & {$[0.004]^{* * *}$} & {$[0.000]^{* * *}$} & {$[0.005]^{* * *}$} & {$[0.003]^{* * *}$} \\
\hline \multirow[t]{2}{*}{ Cash-flow rights } & -37.998 & -0.267 & 28.639 & -0.302 \\
\hline & {$[0.023]^{* *}$} & {$[0.003]^{* * *}$} & {$[0.011]^{* *}$} & {$[0.094]^{*}$} \\
\hline \multirow[t]{2}{*}{ Leverage } & 19.163 & 0.070 & -17.696 & 0.186 \\
\hline & {$[0.043]^{* *}$} & {$[0.693]$} & {$[0.083]^{*}$} & {$[0.422]$} \\
\hline \multirow[t]{2}{*}{ Tangibility } & -12.230 & -0.038 & 22.900 & -0.131 \\
\hline & {$[0.020]^{* *}$} & [0.159] & {$[0.016]^{* *}$} & {$[0.240]$} \\
\hline \multirow[t]{2}{*}{ Log assets } & -0.658 & -0.003 & 0.766 & -0.016 \\
\hline & {$[0.128]$} & {$[0.014]^{* *}$} & {$[0.071]^{*}$} & {$[0.218]$} \\
\hline \multirow[t]{2}{*}{ Profitability } & -93.518 & -0.410 & 12.590 & -1.054 \\
\hline & {$[0.017]^{* *}$} & {$[0.022]^{* *}$} & {$[0.064]^{*}$} & {$[0.252]$} \\
\hline \multirow[t]{2}{*}{ Cash-flow volatility } & 2.390 & 0.007 & -0.271 & 0.025 \\
\hline & {$[0.017]^{* *}$} & [0.168] & {$[0.069]^{*}$} & {$[0.146]$} \\
\hline \multirow[t]{2}{*}{ S\&P rating } & 6.361 & 0.021 & -1.723 & 0.093 \\
\hline & {$[0.064]^{*}$} & {$[0.084]^{*}$} & {$[0.127]$} & {$[0.030]^{* *}$} \\
\hline \multirow[t]{2}{*}{ No rating dummy } & 4.271 & 0.020 & -26.160 & 0.138 \\
\hline & {$[0.022]^{* *}$} & {$[0.032]^{* *}$} & {$[0.021]^{* *}$} & {$[0.089]^{*}$} \\
\hline \multirow[t]{2}{*}{$Q$} & -2.950 & -0.022 & 2.605 & 0.059 \\
\hline & {$[0.164]$} & {$[0.072]^{*}$} & {$[0.425]$} & {$[0.644]$} \\
\hline \multirow[t]{2}{*}{ Performance pricing dummy } & -4.431 & -0.022 & 9.849 & -0.110 \\
\hline & {$[0.012]^{* *}$} & {$[0.090]^{*}$} & {$[0.060]^{*}$} & {$[0.276]$} \\
\hline \multirow[t]{2}{*}{ Term loan dummy } & 14.500 & 0.052 & -10.448 & 0.071 \\
\hline & {$[0.029]^{* *}$} & {$[0.024]^{* *}$} & [0.189] & {$[0.157]$} \\
\hline
\end{tabular}

(Continued on the next page) 


\section{Table 5 Instrumental variables estimation}

(Continued)

\begin{tabular}{|c|c|c|c|c|}
\hline & (1) & (2) & (3) & (4) \\
\hline & \multicolumn{2}{|c|}{ Syndicate Concentration } & \multicolumn{2}{|c|}{ Syndicate Composition } \\
\hline & $\begin{array}{l}\text { Percentage of loan } \\
\text { held by lead } \\
\text { arranger }(\%)\end{array}$ & $\begin{array}{l}\text { Herfindahl } \\
\text { index of } \\
\text { lenders' shares }\end{array}$ & $\begin{array}{l}\text { Percentage of loan } \\
\text { held by foreign } \\
\text { lenders }(\%)\end{array}$ & $\begin{array}{l}\text { Average Syndicate } \\
\text { Industry expertise } \\
(\%)\end{array}$ \\
\hline \multirow[t]{2}{*}{ Log loan size } & -4.650 & -0.027 & 7.995 & 0.056 \\
\hline & {$[0.014]^{* *}$} & {$[0.021]^{* *}$} & {$[0.062]^{*}$} & {$[0.154]$} \\
\hline \multirow[t]{2}{*}{ Log loan maturity } & 10.806 & -0.057 & -10.089 & 0.146 \\
\hline & {$[0.053]^{*}$} & {$[0.023]^{* *}$} & {$[0.166]$} & {$[0.012]^{* *}$} \\
\hline \multirow[t]{2}{*}{ Sovereign risk rating } & 12.389 & 0.034 & -10.767 & 0.068 \\
\hline & {$[0.085]^{*}$} & {$[0.300]$} & {$[0.254]$} & {$[0.165]$} \\
\hline \multirow[t]{2}{*}{ Private credit to GDP } & -4.857 & -0.022 & 25.304 & 0.068 \\
\hline & {$[0.064]^{*}$} & {$[0.305]$} & {$[0.117]$} & [0.185] \\
\hline \multirow[t]{2}{*}{ Log GDP per capita } & -15.700 & -0.044 & 0.953 & -0.080 \\
\hline & {$[0.272]$} & {$[0.380]$} & {$[0.387]$} & {$[0.148]$} \\
\hline Loan purpose dummies & Yes & Yes & Yes & Yes \\
\hline Country effects & Yes & Yes & Yes & Yes \\
\hline Industry effects & Yes & Yes & Yes & Yes \\
\hline Time effects & Yes & Yes & Yes & Yes \\
\hline Number of observations & 8,282 & 8,282 & 8,282 & 8,282 \\
\hline Number of firms & 2,167 & 2,167 & 2,167 & 2,167 \\
\hline Adjusted $\mathrm{R}^{2}$ & 0.351 & 0.155 & 0.459 & 0.188 \\
\hline
\end{tabular}




\section{Table 6 Lead arranger's reputation and lending relationship with the borrowing firm}

This table presents regression results on the effect of the lead arranger's reputation and lending relationship with the borrowing firm on the relation between the control-ownership wedge and syndicate structure. The dependent variables are the percentage of loan held by the lead arranger (columns 1 and 2), the Herfindahl index of lenders' shares in the loan (columns 3 and 4), the percentage of loan held by all foreign lenders (columns 5 and 6), and the average syndicate industry expertise (columns 7 and 8). The control-ownership wedge is defined as the difference between the control rights and cash-flow rights of the largest ultimate owner of the firm. Top ten lender is a dummy variable that equals one if the lead arranger is ranked as one of the top ten lenders in the syndicated loan market for the period from 1996 to 2008. Lending relationship is defined as the amount of loans the lead arranger has made to the borrower during the previous five years, divided by the total amount of loans made to the borrower by all banks during the previous five years. Definitions of all the other variables are reported in Table 1. $P$-Values based on robust standard errors clustered by firm are reported in brackets. Significance at the $10 \%, 5 \%$, and $1 \%$ level is indicated by $* * *$, and $* * *$, respectively.

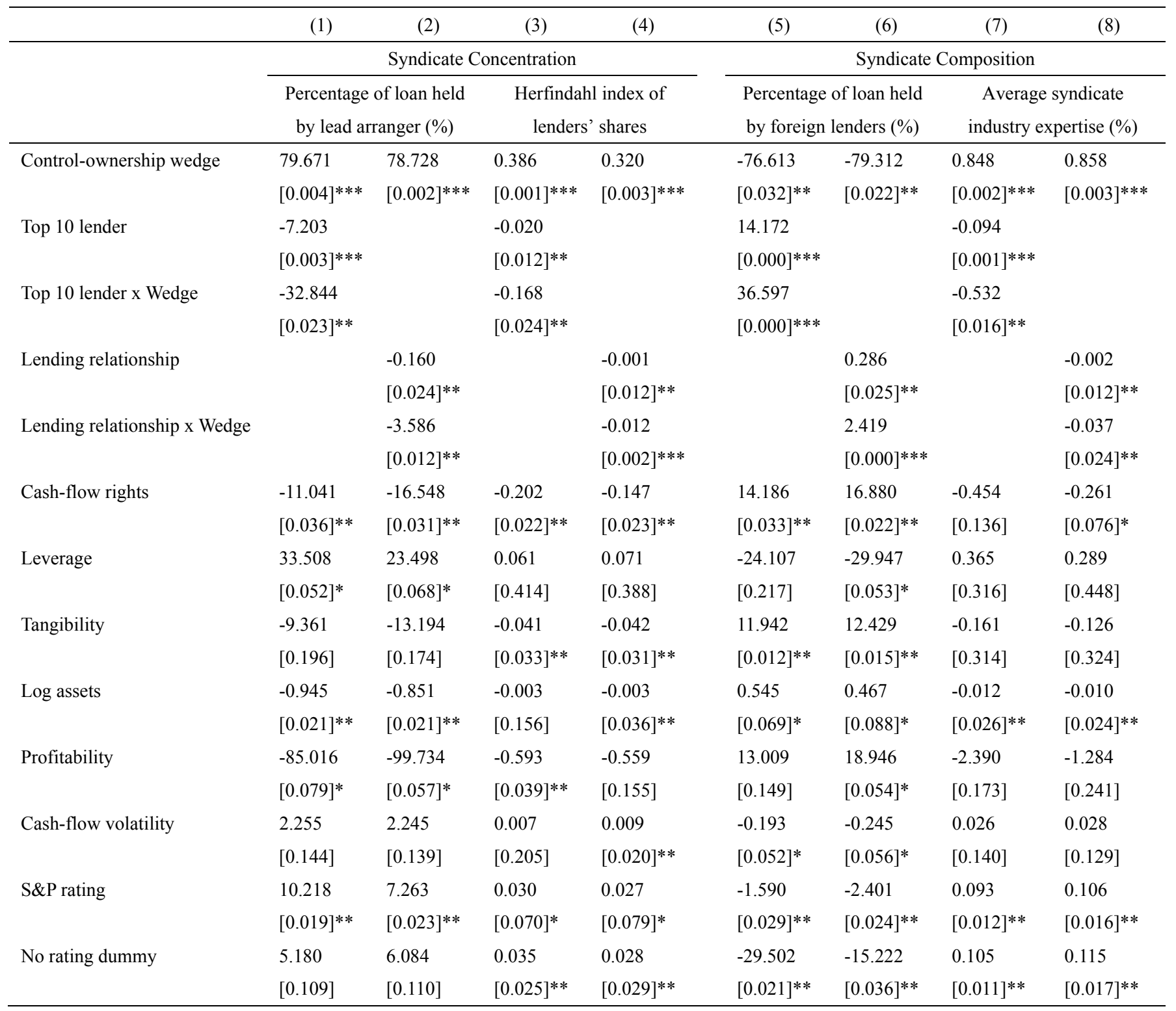

(Continued on the next page) 
Table 6 Lead arranger's reputation and lending relationship with the borrowing firm (Continued)

\begin{tabular}{|c|c|c|c|c|c|c|c|c|}
\hline & (1) & (2) & (3) & (4) & $(5)$ & (6) & (7) & (8) \\
\hline & \multicolumn{4}{|c|}{ Syndicate Concentration } & \multicolumn{4}{|c|}{ Syndicate Composition } \\
\hline & \multicolumn{2}{|c|}{$\begin{array}{l}\text { Percentage of loan held } \\
\text { by lead arranger }(\%)\end{array}$} & \multicolumn{2}{|c|}{$\begin{array}{c}\text { Herfindahl index of } \\
\text { lenders' shares }\end{array}$} & \multicolumn{2}{|c|}{$\begin{array}{l}\text { Percentage of loan held } \\
\text { by foreign lenders }(\%)\end{array}$} & \multicolumn{2}{|c|}{$\begin{array}{c}\text { Average syndicate } \\
\text { industry expertise (\%) }\end{array}$} \\
\hline \multirow[t]{2}{*}{$Q$} & -4.989 & -3.692 & -0.021 & -0.017 & 2.720 & 1.534 & 0.252 & 0.160 \\
\hline & {$[0.125]$} & {$[0.065]^{*}$} & {$[0.407]$} & {$[0.483]$} & {$[0.258]$} & {$[0.551]$} & {$[0.128]$} & {$[0.138]$} \\
\hline \multirow[t]{2}{*}{ Performance pricing dummy } & -5.004 & -5.361 & -0.018 & -0.025 & 7.359 & 9.910 & -0.339 & -0.187 \\
\hline & {$[0.070]^{*}$} & {$[0.013]^{* *}$} & {$[0.070]^{*}$} & {$[0.072]^{*}$} & {$[0.137]$} & {$[0.033]^{* *}$} & {$[0.021]^{* *}$} & {$[0.059]^{*}$} \\
\hline \multirow[t]{2}{*}{ Term loan dummy } & 13.905 & 14.748 & 0.054 & 0.054 & -7.291 & -7.188 & 0.110 & 0.109 \\
\hline & {$[0.137]$} & {$[0.127]$} & {$[0.030]^{* *}$} & {$[0.031]^{* *}$} & {$[0.237]$} & {$[0.227]$} & {$[0.013]^{* *}$} & {$[0.019]^{* *}$} \\
\hline \multirow[t]{2}{*}{ Log loan size } & -4.237 & -5.020 & -0.020 & -0.026 & 4.566 & 7.804 & 0.099 & 0.052 \\
\hline & {$[0.025]^{* *}$} & {$[0.021]^{* *}$} & {$[0.031]^{* *}$} & {$[0.012]^{* *}$} & {$[0.080]^{*}$} & {$[0.079]^{*}$} & {$[0.085]^{*}$} & {$[0.167]$} \\
\hline \multirow[t]{2}{*}{ Log loan maturity } & -9.725 & -11.378 & -0.054 & -0.053 & -6.617 & -7.444 & 0.132 & 0.136 \\
\hline & {$[0.026]^{* *}$} & {$[0.011]^{* *}$} & {$[0.063]^{*}$} & {$[0.073]^{*}$} & {$[0.086]^{*}$} & {$[0.058]^{*}$} & {$[0.031]^{* *}$} & {$[0.030]^{* *}$} \\
\hline \multirow[t]{2}{*}{ Sovereign risk rating } & 14.836 & 12.329 & 0.031 & 0.033 & -8.087 & -11.842 & 0.074 & 0.084 \\
\hline & {$[0.023]^{* *}$} & {$[0.064]^{*}$} & {$[0.906]$} & {$[0.421]$} & {$[0.318]$} & {$[0.192]$} & {$[0.211]$} & {$[0.145]$} \\
\hline \multirow[t]{2}{*}{ Private credit to GDP } & -6.840 & -5.072 & -0.010 & -0.017 & 9.311 & 13.774 & 0.083 & 0.070 \\
\hline & {$[0.023]^{* *}$} & {$[0.073]^{*}$} & {$[0.396]$} & {$[0.051]^{*}$} & {$[0.257]$} & {$[0.174]$} & {$[0.085]^{*}$} & {$[0.012]^{* *}$} \\
\hline \multirow[t]{2}{*}{ Log GDP per capita } & -16.729 & -14.182 & -0.044 & -0.046 & 2.239 & 2.851 & -0.079 & -0.089 \\
\hline & {$[0.270]$} & {$[0.079]^{*}$} & {$[0.366]$} & {$[0.279]$} & {$[0.431]$} & {$[0.264]$} & {$[0.164]$} & {$[0.128]$} \\
\hline Loan purpose dummies & Yes & Yes & Yes & Yes & Yes & Yes & Yes & Yes \\
\hline Country effects & Yes & Yes & Yes & Yes & Yes & Yes & Yes & Yes \\
\hline Industry effects & Yes & Yes & Yes & Yes & Yes & Yes & Yes & Yes \\
\hline Time effects & Yes & Yes & Yes & Yes & Yes & Yes & Yes & Yes \\
\hline Number of observations & 8,282 & 8,282 & 8,282 & 8,282 & 8,282 & 8,282 & 8,282 & 8,282 \\
\hline Number of firms & 2,167 & 2,167 & 2,167 & 2,167 & 2,167 & 2,167 & 2,167 & 2,167 \\
\hline Adjusted $\mathrm{R}^{2}$ & 0.359 & 0.351 & 0.156 & 0.157 & 0.473 & 0.459 & 0.226 & 0.213 \\
\hline
\end{tabular}




\section{Table 7 Borrowing firm informational opacity}

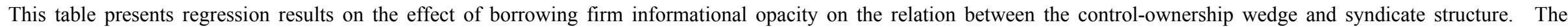

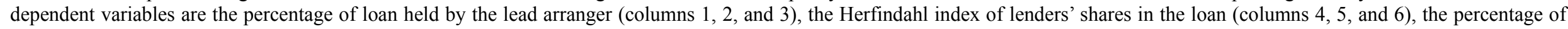

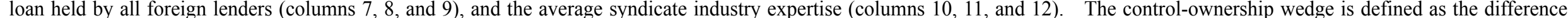

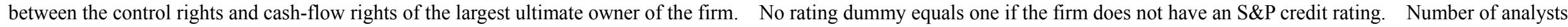

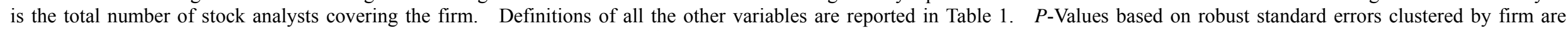
reported in brackets. Significance at the $10 \%, 5 \%$, and $1 \%$ level is indicated by $* * *$, and $* * *$, respectively.

\begin{tabular}{|c|c|c|c|c|c|c|c|c|c|c|c|c|}
\hline & (1) & (2) & (3) & (4) & $(5)$ & (6) & (7) & $(8)$ & (9) & $(10)$ & $(11)$ & $(12)$ \\
\hline & \multicolumn{6}{|c|}{ Syndicate Concentration } & \multicolumn{6}{|c|}{ Syndicate Composition } \\
\hline & \multicolumn{3}{|c|}{$\begin{array}{c}\text { Percentage of loan } \\
\text { held by lead arranger }(\%)\end{array}$} & \multicolumn{3}{|c|}{$\begin{array}{l}\text { Herfindahl index } \\
\text { of lenders' shares }\end{array}$} & \multicolumn{3}{|c|}{$\begin{array}{c}\text { Percentage of loan } \\
\text { held by foreign lenders (\%) }\end{array}$} & \multicolumn{3}{|c|}{$\begin{array}{l}\text { Average syndicate } \\
\text { industry expertise (\%) }\end{array}$} \\
\hline \multirow[t]{2}{*}{ Control-ownership wedge } & 90.624 & 115.302 & 102.705 & 0.507 & 0.543 & 0.350 & -108.222 & -71.747 & -117.343 & 0.674 & 0.557 & 0.753 \\
\hline & {$[0.001]^{* * *}$} & {$[0.004]^{* * *}$} & {$[0.007]^{* * *}$} & {$[0.005]^{* * *}$} & {$[0.004]^{* * *}$} & {$[0.012]^{* *}$} & {$[0.014]^{* *}$} & {$[0.028]^{* *}$} & {$[0.019]^{* *}$} & {$[0.002]^{* * *}$} & {$[0.004]^{* * *}$} & {$[0.002]^{* * *}$} \\
\hline \multirow[t]{2}{*}{ Log assets $x$ Wedge } & -18.663 & & & -0.080 & & & 23.243 & & & -0.117 & & \\
\hline & {$[0.022]^{* *}$} & & & {$[0.027]^{* *}$} & & & {$[0.022]^{* *}$} & & & {$[0.034]^{* *}$} & & \\
\hline \multirow[t]{2}{*}{ No rating dummy $\mathrm{x}$ Wedge } & & 61.589 & & & 0.297 & & & -41.976 & & & 0.634 & \\
\hline & & {$[0.023]^{* *}$} & & & {$[0.028]^{* *}$} & & & {$[0.025]^{* *}$} & & & {$[0.024]^{* *}$} & \\
\hline \multirow[t]{2}{*}{ Number of analysts $x$ Wedge } & & & -3.017 & & & -0.015 & & & 5.032 & & & -0.036 \\
\hline & & & {$[0.035]^{* *}$} & & & {$[0.027]^{* *}$} & & & {$[0.024]^{* *}$} & & & {$[0.015]^{* *}$} \\
\hline \multirow[t]{2}{*}{ Number of analysts } & & & -0.431 & & & -0.002 & & & 0.523 & & & -0.005 \\
\hline & & & {$[0.020]^{* *}$} & & & {$[0.017]^{* *}$} & & & {$[0.017]^{* *}$} & & & {$[0.024]^{* *}$} \\
\hline Log assets & {$[0.032]^{* *}$} & {$[0.024]^{* *}$} & {$[0.012]^{* *}$} & {$[0.237]$} & {$[0.145]$} & {$[0.123]$} & {$[0.032]^{* *}$} & {$[0.084]^{*}$} & {$[0.033]^{* *}$} & {$[0.021]^{* *}$} & {$[0.024]^{* *}$} & {$[0.013]^{* *}$} \\
\hline \multirow[t]{2}{*}{ No rating dummy } & 5.951 & 5.493 & 6.130 & 0.028 & 0.037 & 0.033 & -12.602 & -19.675 & -11.698 & 0.102 & 0.101 & 0.098 \\
\hline & {$[0.095]^{*}$} & {$[0.147]$} & {$[0.084]^{*}$} & {$[0.024]^{* *}$} & {$[0.023]^{* *}$} & {$[0.022]^{* *}$} & {$[0.033]^{* *}$} & {$[0.021]^{* *}$} & {$[0.034]^{* *}$} & {$[0.011]^{* *}$} & {$[0.011]^{* *}$} & {$[0.023]^{* *}$} \\
\hline \multirow[t]{2}{*}{ Cash-flow rights } & -14.590 & -14.634 & -20.444 & -0.081 & -0.076 & -0.113 & 17.226 & 16.731 & 17.139 & -0.348 & -0.233 & -0.415 \\
\hline & {$[0.033]^{* *}$} & {$[0.022]^{* *}$} & {$[0.024]^{* *}$} & {$[0.023]^{* *}$} & {$[0.023]^{* *}$} & {$[0.021]^{* *}$} & {$[0.012]^{* *}$} & {$[0.032]^{* *}$} & {$[0.064]^{*}$} & {$[0.265]$} & {$[0.302]$} & {$[0.258]$} \\
\hline \multirow[t]{2}{*}{ Leverage } & 20.740 & 22.046 & 15.925 & 0.062 & 0.063 & 0.086 & -30.491 & -31.631 & -19.251 & 0.299 & 0.293 & 0.459 \\
\hline & {$[0.083]^{*}$} & {$[0.069]^{*}$} & {$[0.261]$} & {$[0.376]$} & {$[0.381]$} & {$[0.303]$} & {$[0.052]^{*}$} & {$[0.053]^{*}$} & {$[0.251]$} & {$[0.445]$} & {$[0.453]$} & {$[0.280]$} \\
\hline \multirow[t]{2}{*}{ Tangibility } & -9.006 & -14.418 & -16.073 & -0.044 & -0.041 & -0.035 & 11.317 & 11.437 & 13.604 & -0.117 & -0.116 & -0.216 \\
\hline & {$[0.189]$} & {$[0.174]$} & {$[0.091]^{*}$} & {$[0.024]^{* *}$} & {$[0.032]^{* *}$} & {$[0.051]^{*}$} & {$[0.062]^{*}$} & {$[0.059]^{*}$} & {$[0.015]^{* *}$} & {$[0.348]$} & {$[0.356]$} & {$[0.070]^{*}$} \\
\hline
\end{tabular}

(Continued on the next page) 


\section{Table 7 Borrowing firm informational opacity}

(Continued)

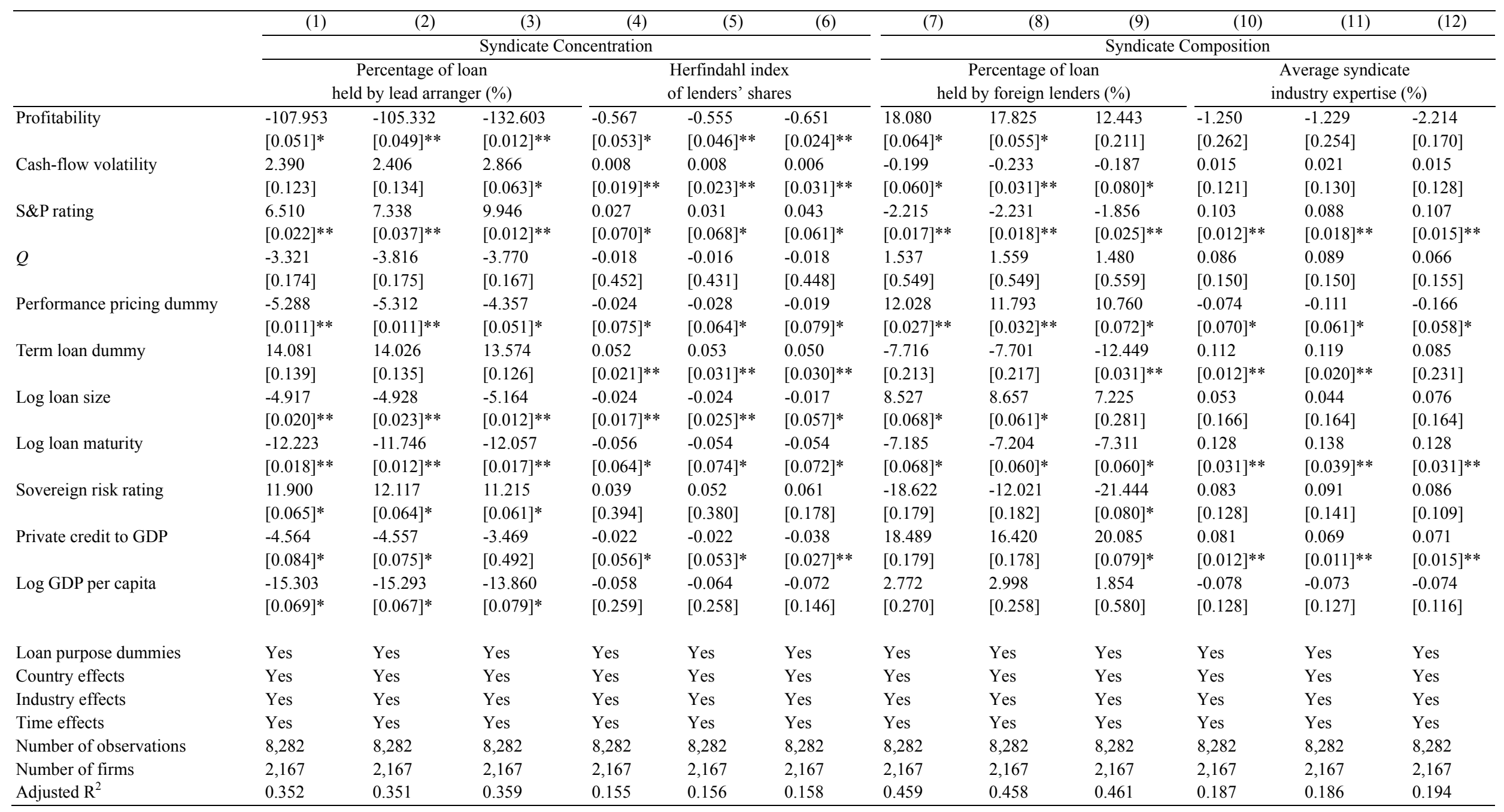




\section{Table 8 Borrowing firm cash-flow rights dispersion across large owners}

This table presents regression results on the effect of borrowing firm cash-flow rights dispersion across large owners on the relation between the control-ownership wedge and syndicate structure. The dependent variables are the percentage of loan held by the lead arranger (column 1), the Herfindahl index of lenders' shares in the loan (column 2), the percentage of loan held by all foreign lenders (column 3), and the average syndicate industry expertise (column 4). The control-ownership wedge is defined as the difference between the control rights and cash-flow rights of the largest ultimate owner of the firm. Cash-flow rights dispersion across large owners is defined as the difference between the cash-flow rights of the largest owner and the cash-flow rights of the second largest owner (Laeven and Levine, 2008). Definitions of all the other variables are reported in Table 1. P-Values based on robust standard errors clustered by firm are reported in brackets. Significance at the $10 \%, 5 \%$, and $1 \%$ level is indicated by $*, * *$, and $* * *$, respectively.

\begin{tabular}{|c|c|c|c|c|}
\hline & (1) & $(2)$ & (3) & (4) \\
\hline & \multicolumn{2}{|c|}{ Syndicate Concentration } & \multicolumn{2}{|c|}{ Syndicate Composition } \\
\hline & $\begin{array}{l}\text { Percentage of } \\
\text { loan held by lead } \\
\text { arranger }(\%)\end{array}$ & $\begin{array}{l}\text { Herfindahl } \\
\text { index of } \\
\text { lenders' shares }\end{array}$ & $\begin{array}{l}\text { Percentage of loan } \\
\text { held by foreign } \\
\text { lenders }(\%)\end{array}$ & $\begin{array}{l}\text { Average syndicate } \\
\text { industry expertise } \\
(\%)\end{array}$ \\
\hline \multirow[t]{2}{*}{ Control-ownership wedge } & 96.376 & 0.319 & -103.141 & 0.951 \\
\hline & {$[0.008]^{* * *}$} & {$[0.002]^{* * *}$} & {$[0.015]^{* *}$} & {$[0.002]^{* * *}$} \\
\hline \multirow[t]{2}{*}{ Cash-flow rights dispersion } & 82.677 & 0.260 & -56.595 & 0.375 \\
\hline & {$[0.012]^{* *}$} & {$[0.000]^{* * *}$} & {$[0.016]^{* *}$} & {$[0.003]^{* * *}$} \\
\hline \multirow[t]{2}{*}{ Cash-flow rights dispersion $\mathrm{x}$ Wedge } & 204.716 & 0.683 & -144.172 & 1.973 \\
\hline & {$[0.003]^{* * *}$} & {$[0.000]^{* * *}$} & {$[0.000]^{* * *}$} & {$[0.015]^{* *}$} \\
\hline \multirow[t]{2}{*}{ Cash-flow rights } & -17.160 & -0.056 & 18.274 & -0.112 \\
\hline & {$[0.033]^{* *}$} & {$[0.032]^{* *}$} & {$[0.034]^{* *}$} & {$[0.053]^{*}$} \\
\hline \multirow[t]{2}{*}{ Leverage } & 15.087 & 0.067 & -30.551 & 0.336 \\
\hline & {$[0.059]^{*}$} & {$[0.377]$} & {$[0.063]^{*}$} & {$[0.461]$} \\
\hline \multirow[t]{2}{*}{ Tangibility } & -12.140 & -0.033 & 11.473 & -0.138 \\
\hline & {$[0.183]$} & {$[0.035]^{* *}$} & {$[0.011]^{* *}$} & [0.394] \\
\hline \multirow[t]{2}{*}{ Log assets } & -0.538 & -0.004 & 0.487 & -0.023 \\
\hline & {$[0.030]^{* *}$} & {$[0.257]$} & {$[0.187]$} & {$[0.011]^{* *}$} \\
\hline \multirow[t]{2}{*}{ Profitability } & -148.678 & -0.411 & 17.796 & -1.752 \\
\hline & {$[0.051]^{*}$} & {$[0.032]^{* *}$} & {$[0.064]^{*}$} & {$[0.267]$} \\
\hline \multirow[t]{2}{*}{ Cash-flow volatility } & 2.402 & 0.009 & -0.222 & 0.026 \\
\hline & {$[0.134]$} & {$[0.022]^{* *}$} & {$[0.149]$} & {$[0.129]$} \\
\hline \multirow[t]{2}{*}{ S\&P rating } & 6.174 & 0.021 & -2.091 & 0.116 \\
\hline & {$[0.023]^{* *}$} & {$[0.070]^{*}$} & {$[0.241]$} & {$[0.017]^{* *}$} \\
\hline \multirow[t]{2}{*}{ No rating dummy } & 6.201 & 0.029 & -15.761 & 0.119 \\
\hline & {$[0.079]^{*}$} & {$[0.165]$} & {$[0.033]^{* *}$} & {$[0.011]^{* *}$} \\
\hline \multirow[t]{2}{*}{$Q$} & -3.250 & -0.018 & 1.595 & 0.017 \\
\hline & {$[0.166]$} & {$[0.425]$} & {$[0.539]$} & {$[0.156]$} \\
\hline
\end{tabular}

(Continued on the next page) 
Table 8 Borrowing firm cash-flow rights dispersion across large owners

(Continued)

\begin{tabular}{|c|c|c|c|c|}
\hline & (1) & (2) & (3) & (4) \\
\hline & \multicolumn{2}{|c|}{ Syndicate Concentration } & \multicolumn{2}{|c|}{ Syndicate Composition } \\
\hline & $\begin{array}{l}\text { Percentage of } \\
\text { loan held by lead } \\
\text { arranger }(\%)\end{array}$ & $\begin{array}{l}\text { Herfindahl } \\
\text { index of } \\
\text { lenders' shares }\end{array}$ & $\begin{array}{l}\text { Percentage of loan } \\
\text { held by foreign } \\
\text { lenders }(\%)\end{array}$ & $\begin{array}{l}\text { Average syndicate } \\
\text { industry expertise } \\
(\%)\end{array}$ \\
\hline \multirow[t]{2}{*}{ Performance pricing dummy } & -4.334 & -0.027 & 11.411 & -0.127 \\
\hline & {$[0.134]$} & {$[0.070]^{*}$} & {$[0.032]^{* *}$} & {$[0.088]^{*}$} \\
\hline \multirow[t]{2}{*}{ Term loan dummy } & 13.804 & 0.053 & -7.679 & 0.120 \\
\hline & {$[0.176]$} & {$[0.031]^{* *}$} & {$[0.207]$} & {$[0.012]^{* *}$} \\
\hline \multirow[t]{2}{*}{ Log loan size } & -4.907 & -0.026 & 8.523 & 0.041 \\
\hline & {$[0.037]^{* *}$} & {$[0.012]^{* *}$} & {$[0.060]^{*}$} & {$[0.163]$} \\
\hline \multirow[t]{2}{*}{ Log loan maturity } & -10.972 & -0.058 & -7.012 & 0.133 \\
\hline & {$[0.021]^{* *}$} & {$[0.065]^{*}$} & {$[0.051]^{*}$} & {$[0.148]$} \\
\hline \multirow[t]{2}{*}{ Sovereign risk rating } & 11.920 & 0.031 & -12.920 & 0.074 \\
\hline & {$[0.074]^{*}$} & {$[0.408]$} & {$[0.185]$} & {$[0.140]$} \\
\hline \multirow[t]{2}{*}{ Private credit to GDP } & -2.299 & -0.027 & 16.328 & 0.037 \\
\hline & {$[0.053]^{*}$} & {$[0.088]^{*}$} & {$[0.183]$} & {$[0.019]^{* *}$} \\
\hline \multirow[t]{2}{*}{ Log GDP per capita } & -15.371 & -0.043 & 2.923 & -0.045 \\
\hline & {$[0.284]$} & {$[0.363]$} & {$[0.247]$} & {$[0.133]$} \\
\hline Loan purpose dummies & Yes & Yes & Yes & Yes \\
\hline Country effects & Yes & Yes & Yes & Yes \\
\hline Industry effects & Yes & Yes & Yes & Yes \\
\hline Time effects & Yes & Yes & Yes & Yes \\
\hline Number of observations & 8,282 & 8,282 & 8,282 & 8,282 \\
\hline Number of firms & 2,167 & 2,167 & 2,167 & 2,167 \\
\hline Adjusted $\mathrm{R}^{2}$ & 0.351 & 0.155 & 0.458 & 0.187 \\
\hline
\end{tabular}


Table 9 Legal rights and institutions

This table presents regression results on the effect of legal rights and institutions on the relation between the control-ownership wedge and syndicate structure. The dependent variables are the percentage of loan held by the lead arranger (columns 1 and 2), the Herfindahl index of lenders' shares in the loan (columns 3 and 4), the percentage of loan held by all foreign lenders (columns 5 and 6), and the average syndicate industry expertise (columns 7 and 8). The control-ownership wedge is defined as the difference between the control rights and cash-flow rights of the largest ultimate owner of the firm. Anti-self-dealing is an index constructed by Djankov et al. (2008), with higher values indicating stronger protection of investors against self-dealing by controlling shareholders. Credit information sharing is a dummy variable that takes the value of one if an information sharing agency operates in the country of the borrower in the observation year (Djankov et al., 2007). Definitions of all the other variables are reported in Table 1. P-Values based on robust standard errors clustered by firm are reported in brackets. Significance at the $10 \%, 5 \%$, and $1 \%$ level is indicated by $*, * *$, and $* * *$, respectively.

\begin{tabular}{|c|c|c|c|c|c|c|c|c|}
\hline & (1) & (2) & (3) & (4) & (5) & $(6)$ & (7) & $(8)$ \\
\hline & \multicolumn{4}{|c|}{ Syndicate Concentration } & \multicolumn{4}{|c|}{ Syndicate Composition } \\
\hline & \multicolumn{2}{|c|}{$\begin{array}{c}\text { Percentage of loan held } \\
\text { by lead arranger }(\%)\end{array}$} & \multicolumn{2}{|c|}{$\begin{array}{l}\text { Herfindahl index } \\
\text { of lenders' shares }\end{array}$} & \multicolumn{2}{|c|}{$\begin{array}{l}\text { Percentage of loan held } \\
\text { by foreign lenders (\%) }\end{array}$} & \multicolumn{2}{|c|}{$\begin{array}{c}\text { Average syndicate } \\
\text { industry expertise (\%) }\end{array}$} \\
\hline \multirow[t]{2}{*}{ Control-ownership wedge } & 96.337 & 120.996 & 0.615 & 0.562 & -123.144 & -89.852 & 0.735 & 0.823 \\
\hline & {$[0.002]^{* * *}$} & {$[0.002]^{* * *}$} & {$[0.003]^{* * *}$} & {$[0.003]^{* * *}$} & {$[0.002]^{* * *}$} & {$[0.021]^{* *}$} & {$[0.003]^{* * *}$} & {$[0.001]^{* * *}$} \\
\hline \multirow[t]{2}{*}{ Anti-self-dealing } & -18.308 & & -0.145 & & 26.242 & & -0.207 & \\
\hline & {$[0.016]^{* *}$} & & {$[0.003]^{* * *}$} & & {$[0.002]^{* * *}$} & & {$[0.012]^{* *}$} & \\
\hline \multirow[t]{2}{*}{ Anti-self-dealing x Wedge } & -90.768 & & -0.471 & & 121.375 & & -0.701 & \\
\hline & {$[0.011]^{* *}$} & & {$[0.011]^{* *}$} & & {$[0.041]^{* *}$} & & {$[0.022]^{* *}$} & \\
\hline \multirow[t]{2}{*}{ Credit information sharing } & & -5.713 & & -0.029 & & 4.782 & & -0.038 \\
\hline & & {$[0.014]^{* *}$} & & {$[0.023]^{* *}$} & & {$[0.001]^{* * *}$} & & {$[0.002]^{* * *}$} \\
\hline \multirow[t]{2}{*}{ Credit information sharing $\mathrm{x}$ Wedge } & & -57.875 & & -0.328 & & 51.246 & & -0.405 \\
\hline & & {$[0.012]^{* *}$} & & {$[0.015]^{* *}$} & & {$[0.011]^{* *}$} & & {$[0.021]^{* *}$} \\
\hline \multirow[t]{2}{*}{ Cash-flow rights } & -17.901 & -14.145 & -0.100 & -0.072 & 17.457 & 16.665 & -0.364 & -0.432 \\
\hline & {$[0.028]^{* *}$} & {$[0.062]^{*}$} & {$[0.029]^{* *}$} & {$[0.053]^{*}$} & {$[0.031]^{* *}$} & {$[0.052]^{*}$} & {$[0.261]$} & {$[0.021]^{* *}$} \\
\hline \multirow[t]{2}{*}{ Leverage } & 19.007 & 22.592 & 0.094 & 0.081 & -27.826 & -31.262 & 0.186 & 0.277 \\
\hline & {$[0.122]$} & {$[0.063]^{*}$} & {$[0.141]$} & {$[0.372]$} & {$[0.282]$} & {$[0.062]^{*}$} & {$[0.722]$} & {$[0.472]$} \\
\hline \multirow[t]{2}{*}{ Tangibility } & -20.797 & -12.744 & -0.033 & -0.042 & 12.912 & 12.037 & -0.072 & -0.128 \\
\hline & {$[0.031]^{* *}$} & {$[0.202]$} & {$[0.053]^{*}$} & {$[0.032]^{* *}$} & {$[0.011]^{* *}$} & {$[0.023]^{* *}$} & {$[0.501]$} & {$[0.362]$} \\
\hline \multirow[t]{2}{*}{ Log assets } & -0.663 & -0.872 & -0.003 & -0.003 & 0.611 & 0.515 & -0.018 & -0.026 \\
\hline & {$[0.131]$} & {$[0.022]^{* *}$} & {$[0.252]$} & {$[0.033]^{* *}$} & {$[0.037]^{* *}$} & {$[0.081]^{*}$} & {$[0.023]^{* *}$} & {$[0.021]^{* *}$} \\
\hline \multirow[t]{2}{*}{ Profitability } & -96.556 & -104.537 & -0.424 & -0.599 & 24.177 & 19.653 & -2.023 & -1.291 \\
\hline & {$[0.071]^{*}$} & {$[0.037]^{* *}$} & {$[0.132]$} & {$[0.036]^{* *}$} & {$[0.055]^{*}$} & {$[0.051]^{*}$} & {$[0.201]$} & {$[0.252]$} \\
\hline \multirow[t]{2}{*}{ Cash-flow volatility } & 2.224 & 2.455 & 0.010 & 0.009 & -0.302 & -0.183 & 0.012 & 0.018 \\
\hline & {$[0.172]$} & {$[0.028]^{* *}$} & {$[0.125]$} & {$[0.026]^{* *}$} & {$[0.061]^{*}$} & {$[0.119]$} & {$[0.091]^{*}$} & {$[0.132]$} \\
\hline \multirow[t]{2}{*}{ S\&P rating } & 7.395 & 7.898 & 0.028 & 0.028 & -2.281 & -1.623 & 0.098 & 0.085 \\
\hline & {$[0.032]^{* *}$} & {$[0.021]^{* *}$} & {$[0.032]^{* *}$} & {$[0.071]^{*}$} & {$[0.012]^{* *}$} & {$[0.171]$} & {$[0.018]^{* *}$} & {$[0.012]^{* *}$} \\
\hline \multirow[t]{2}{*}{ No rating dummy } & 6.282 & 6.276 & 0.039 & 0.024 & -23.055 & -17.023 & 0.103 & 0.104 \\
\hline & {$[0.081]^{*}$} & {$[0.083]^{*}$} & {$[0.028]^{* *}$} & {$[0.112]$} & {$[0.025]^{* *}$} & {$[0.032]^{* *}$} & {$[0.012]^{* *}$} & {$[0.012]^{* *}$} \\
\hline
\end{tabular}

(Continued on the next page) 
Table 9 Legal rights and institutions

(Continued)

\begin{tabular}{|c|c|c|c|c|c|c|c|c|}
\hline & (1) & (2) & (3) & (4) & $(5)$ & $(6)$ & (7) & $(8)$ \\
\hline & \multicolumn{4}{|c|}{ Syndicate Concentration } & \multicolumn{4}{|c|}{ Syndicate Composition } \\
\hline & \multicolumn{2}{|c|}{$\begin{array}{c}\text { Percentage of loan held } \\
\text { by lead arranger }(\%)\end{array}$} & \multicolumn{2}{|c|}{$\begin{array}{l}\text { Herfindahl index } \\
\text { of lenders' shares }\end{array}$} & \multicolumn{2}{|c|}{$\begin{array}{l}\text { Percentage of loan held } \\
\text { by foreign lenders }(\%)\end{array}$} & \multicolumn{2}{|c|}{$\begin{array}{c}\text { Average syndicate } \\
\text { industry expertise (\%) }\end{array}$} \\
\hline \multirow[t]{2}{*}{$Q$} & -2.424 & -5.654 & -0.017 & -0.020 & 0.871 & 1.137 & 0.155 & 0.106 \\
\hline & {$[0.183]$} & {$[0.083]^{*}$} & {$[0.713]$} & {$[0.072]^{*}$} & {$[0.742]$} & {$[0.672]$} & {$[0.131]$} & {$[0.143]$} \\
\hline \multirow[t]{2}{*}{ Performance pricing dummy } & -5.176 & -5.174 & -0.021 & -0.024 & 12.196 & 12.586 & -0.082 & -0.072 \\
\hline & {$[0.019]^{* *}$} & {$[0.011]^{* *}$} & {$[0.072]^{*}$} & {$[0.070]^{*}$} & {$[0.021]^{* *}$} & {$[0.022]^{* *}$} & {$[0.093]^{*}$} & {$[0.063]^{*}$} \\
\hline \multirow[t]{2}{*}{ Term loan dummy } & 14.434 & 14.502 & 0.042 & 0.055 & -10.251 & -7.276 & 0.128 & 0.114 \\
\hline & {$[0.172]$} & {$[0.153]$} & {$[0.233]$} & {$[0.023]^{* *}$} & {$[0.022]^{* *}$} & {$[0.242]$} & {$[0.042]^{* *}$} & {$[0.011]^{* *}$} \\
\hline \multirow[t]{2}{*}{ Log loan size } & -3.892 & -4.972 & -0.028 & -0.023 & 9.672 & 8.512 & 0.057 & 0.052 \\
\hline & {$[0.211]$} & {$[0.022]^{* *}$} & {$[0.021]^{* *}$} & {$[0.012]^{* *}$} & {$[0.023]^{* *}$} & {$[0.072]^{*}$} & {$[0.021]^{* *}$} & {$[0.172]$} \\
\hline \multirow[t]{2}{*}{ Log loan maturity } & -10.523 & -12.244 & -0.044 & -0.056 & -8.137 & -7.512 & 0.114 & 0.123 \\
\hline & {$[0.016]^{* *}$} & {$[0.135]$} & {$[0.162]$} & {$[0.073]^{*}$} & {$[0.063]^{*}$} & {$[0.071]^{*}$} & {$[0.023]^{* *}$} & {$[0.021]^{* *}$} \\
\hline \multirow[t]{2}{*}{ Sovereign risk rating } & 12.468 & 12.714 & 0.043 & 0.038 & -16.775 & -18.257 & 0.104 & 0.094 \\
\hline & {$[0.072]^{*}$} & {$[0.072]^{*}$} & {$[0.063]^{*}$} & {$[0.391]$} & {$[0.181]$} & {$[0.151]$} & {$[0.133]$} & {$[0.142]$} \\
\hline \multirow[t]{2}{*}{ Private credit to GDP } & -4.427 & -4.926 & -0.025 & -0.019 & 18.903 & 23.625 & 0.083 & 0.087 \\
\hline & {$[0.081]^{*}$} & {$[0.052]^{*}$} & {$[0.051]^{*}$} & {$[0.052]^{*}$} & {$[0.171]$} & {$[0.133]$} & {$[0.031]^{* *}$} & {$[0.021]^{* *}$} \\
\hline \multirow[t]{2}{*}{ Log GDP per capita } & -14.954 & -15.517 & -0.052 & -0.037 & 3.353 & 1.803 & -0.077 & -0.081 \\
\hline & {$[0.072]^{*}$} & {$[0.063]^{*}$} & {$[0.272]$} & {$[0.313]$} & {$[0.192]$} & {$[0.481]$} & {$[0.141]$} & {$[0.131]$} \\
\hline Loan purpose dummies & Yes & Yes & Yes & Yes & Yes & Yes & Yes & Yes \\
\hline Industry effects & Yes & Yes & Yes & Yes & Yes & Yes & Yes & Yes \\
\hline Time effects & Yes & Yes & Yes & Yes & Yes & Yes & Yes & Yes \\
\hline Number of observations & 8,282 & 8,282 & 8,282 & 8,282 & 8,282 & 8,282 & 8,282 & 8,282 \\
\hline Number of firms & 2,167 & 2,167 & 2,167 & 2,167 & 2,167 & 2,167 & 2,167 & 2,167 \\
\hline Adjusted $\mathrm{R}^{2}$ & 0.342 & 0.344 & 0.145 & 0.132 & 0.441 & 0.436 & 0.172 & 0.172 \\
\hline
\end{tabular}




\section{Table 10 Financial crises}

This table presents the regression results on the effect of financial crises on the relation between the control-ownership wedge and syndicate structure. The dependent variables are the percentage of loan held by the lead arranger (column 1), the Herfindahl index of lenders' shares in the loan (column 2), the percentage of loan held by all foreign lenders (column 3), and the average syndicate industry expertise (column 4). The control-ownership wedge is defined as the difference between the control rights and cash-flow rights of the largest ultimate owner of the firm. Financial crisis is a dummy variable that equals one if the country of the borrower is undergoing a financial crisis in the observation year, as identified in the IMF Banking Crisis Database. Definitions of all the other variables are reported in Table 1. $P$-Values based on robust standard errors clustered by firm are reported in brackets. Significance at the $10 \%, 5 \%$, and $1 \%$ level is indicated by $*, * *$, and ***, respectively.

\begin{tabular}{|c|c|c|c|c|}
\hline & (1) & (2) & (3) & (4) \\
\hline & \multicolumn{2}{|c|}{ Syndicate Concentration } & \multicolumn{2}{|c|}{ Syndicate Composition } \\
\hline & $\begin{array}{l}\text { Percentage of } \\
\text { loan held by lead } \\
\text { arranger }(\%)\end{array}$ & $\begin{array}{l}\text { Herfindahl } \\
\text { index of } \\
\text { lenders' shares }\end{array}$ & $\begin{array}{l}\text { Percentage of loan } \\
\text { held by foreign } \\
\text { lenders (\%) }\end{array}$ & $\begin{array}{l}\text { Average syndicate } \\
\text { industry expertise } \\
(\%)\end{array}$ \\
\hline Control-ownership wedge & $\begin{array}{l}91.504 \\
{[0.002]^{* * *}}\end{array}$ & $\begin{array}{l}0.597 \\
{[0.003]^{* * *}}\end{array}$ & $\begin{array}{l}-59.416 \\
{[0.034]^{* *}}\end{array}$ & $\begin{array}{l}0.759 \\
{[0.002]^{* * *}}\end{array}$ \\
\hline Financial crisis & $\begin{array}{l}8.715 \\
{[0.026]^{* *}}\end{array}$ & $\begin{array}{l}0.054 \\
{[0.000]^{* * *}}\end{array}$ & $\begin{array}{l}-14.835 \\
{[0.000]^{* * *}}\end{array}$ & $\begin{array}{l}0.090 \\
{[0.033]^{* *}}\end{array}$ \\
\hline Financial crisis $x$ Wedge & $\begin{array}{l}39.992 \\
{[0.012]^{* *}}\end{array}$ & $\begin{array}{l}0.186 \\
{[0.034]^{* *}}\end{array}$ & $\begin{array}{l}-36.181 \\
{[0.012]^{* *}}\end{array}$ & $\begin{array}{l}0.506 \\
{[0.035]^{* *}}\end{array}$ \\
\hline Cash-flow rights & $\begin{array}{l}-12.992 \\
{[0.032]^{* *}}\end{array}$ & $\begin{array}{l}-0.123 \\
{[0.023]^{* *}}\end{array}$ & $\begin{array}{l}16.017 \\
{[0.023]^{* *}}\end{array}$ & $\begin{array}{l}-0.451 \\
{[0.260]}\end{array}$ \\
\hline Leverage & $\begin{array}{l}23.404 \\
{[0.060]^{*}}\end{array}$ & $\begin{array}{l}0.068 \\
{[0.365]}\end{array}$ & $\begin{array}{l}-22.135 \\
{[0.167]}\end{array}$ & $\begin{array}{l}0.252 \\
{[0.529]}\end{array}$ \\
\hline Tangibility & $\begin{array}{l}-8.675 \\
{[0.188]}\end{array}$ & $\begin{array}{l}-0.036 \\
{[0.032]^{* *}}\end{array}$ & $\begin{array}{l}12.098 \\
{[0.031]^{* *}}\end{array}$ & $\begin{array}{l}-0.117 \\
{[0.367]}\end{array}$ \\
\hline Log assets & $\begin{array}{l}-0.936 \\
{[0.022]^{* *}}\end{array}$ & $\begin{array}{l}-0.002 \\
{[0.225]}\end{array}$ & $\begin{array}{l}0.755 \\
{[0.056]^{*}}\end{array}$ & $\begin{array}{l}-0.016 \\
{[0.032]^{* *}}\end{array}$ \\
\hline Profitability & $\begin{array}{l}-104.380 \\
{[0.059]^{*}}\end{array}$ & $\begin{array}{l}-0.622 \\
{[0.022]^{* *}}\end{array}$ & $\begin{array}{l}15.675 \\
{[0.084]^{*}}\end{array}$ & $\begin{array}{l}-1.146 \\
{[0.269]}\end{array}$ \\
\hline Cash-flow volatility & $\begin{array}{l}2.320 \\
{[0.134]}\end{array}$ & $\begin{array}{l}0.006 \\
{[0.031]^{* *}}\end{array}$ & $\begin{array}{l}-0.179 \\
{[0.079]^{*}}\end{array}$ & $\begin{array}{l}0.033 \\
{[0.123]}\end{array}$ \\
\hline $\mathrm{S} \& \mathrm{P}$ rating & $\begin{array}{l}8.386 \\
{[0.033]^{* *}}\end{array}$ & $\begin{array}{l}0.033 \\
{[0.059]^{*}}\end{array}$ & $\begin{array}{l}-1.749 \\
{[0.035]^{* *}}\end{array}$ & $\begin{array}{l}0.103 \\
{[0.013]^{* *}}\end{array}$ \\
\hline No rating dummy & $\begin{array}{l}6.794 \\
{[0.071]^{*}}\end{array}$ & $\begin{array}{l}0.047 \\
{[0.020]^{* *}}\end{array}$ & $\begin{array}{l}-21.175 \\
{[0.023]^{* *}}\end{array}$ & $\begin{array}{l}0.105 \\
{[0.018]^{* *}}\end{array}$ \\
\hline$Q$ & $\begin{array}{l}-4.841 \\
{[0.159]}\end{array}$ & $\begin{array}{l}-0.017 \\
{[0.483]}\end{array}$ & $\begin{array}{l}1.428 \\
{[0.573]}\end{array}$ & $\begin{array}{l}0.107 \\
{[0.147]}\end{array}$ \\
\hline
\end{tabular}

(Continued to the next page) 
Table 10 Financial crises

(Continued)

\begin{tabular}{|c|c|c|c|c|}
\hline & $(1)$ & (2) & (3) & (4) \\
\hline & \multicolumn{2}{|c|}{ Syndicate Concentration } & \multicolumn{2}{|c|}{ Syndicate Composition } \\
\hline & $\begin{array}{l}\text { Percentage of } \\
\text { loan held by lead } \\
\text { arranger }(\%)\end{array}$ & $\begin{array}{l}\text { Herfindahl } \\
\text { index of } \\
\text { lenders' shares }\end{array}$ & $\begin{array}{l}\text { Percentage of loan } \\
\text { held by foreign } \\
\text { lenders }(\%)\end{array}$ & $\begin{array}{l}\text { Average syndicate } \\
\text { industry expertise } \\
(\%)\end{array}$ \\
\hline Performance pricing dummy & $\begin{array}{l}-5.291 \\
{[0.021]^{* *}}\end{array}$ & $\begin{array}{l}-0.018 \\
{[0.087]^{*}}\end{array}$ & $\begin{array}{l}8.396 \\
{[0.123]}\end{array}$ & $\begin{array}{l}-0.048 \\
{[0.081]^{*}}\end{array}$ \\
\hline Term loan dummy & $\begin{array}{l}14.204 \\
{[0.118]}\end{array}$ & $\begin{array}{l}0.052 \\
{[0.031]^{* *}}\end{array}$ & $\begin{array}{l}-8.108 \\
{[0.186]}\end{array}$ & $\begin{array}{l}0.113 \\
{[0.022]^{* *}}\end{array}$ \\
\hline Log loan size & $\begin{array}{l}-4.922 \\
{[0.020]^{* *}}\end{array}$ & $\begin{array}{l}-0.024 \\
{[0.012]^{* *}}\end{array}$ & $\begin{array}{l}8.942 \\
{[0.062]^{*}}\end{array}$ & $\begin{array}{l}0.047 \\
{[0.166]}\end{array}$ \\
\hline Log loan maturity & $\begin{array}{l}-12.406 \\
{[0.013]^{* *}}\end{array}$ & $\begin{array}{l}-0.048 \\
{[0.125]}\end{array}$ & $\begin{array}{l}-8.132 \\
{[0.062]^{*}}\end{array}$ & $\begin{array}{l}0.136 \\
{[0.031]^{* *}}\end{array}$ \\
\hline Sovereign risk rating & $\begin{array}{l}11.995 \\
{[0.064]^{*}}\end{array}$ & $\begin{array}{l}0.051 \\
{[0.334]}\end{array}$ & $\begin{array}{l}-15.121 \\
{[0.145]}\end{array}$ & $\begin{array}{l}0.101 \\
{[0.139]}\end{array}$ \\
\hline Private credit to GDP & $\begin{array}{l}-4.271 \\
{[0.188]}\end{array}$ & $\begin{array}{l}-0.030 \\
{[0.039]^{* *}}\end{array}$ & $\begin{array}{l}19.065 \\
{[0.032]^{* *}}\end{array}$ & $\begin{array}{l}0.094 \\
{[0.021]^{* *}}\end{array}$ \\
\hline Log GDP per capita & $\begin{array}{l}-15.208 \\
{[0.070]^{*}}\end{array}$ & $\begin{array}{l}-0.052 \\
{[0.176]}\end{array}$ & $\begin{array}{l}4.089 \\
{[0.149]}\end{array}$ & $\begin{array}{l}-0.087 \\
{[0.132]}\end{array}$ \\
\hline Loan purpose dummies & Yes & Yes & Yes & Yes \\
\hline Country effects & Yes & Yes & Yes & Yes \\
\hline Industry effects & Yes & Yes & Yes & Yes \\
\hline Time effects & Yes & Yes & Yes & Yes \\
\hline Number of observations & 8,282 & 8,282 & 8,282 & 8,282 \\
\hline Number of firms & 2,167 & 2,167 & 2,167 & 2,167 \\
\hline Adjusted $\mathrm{R}^{2}$ & 0.351 & 0.156 & 0.460 & 0.187 \\
\hline
\end{tabular}

